\title{
Effect of Juice and Extracts from Saposhnikovia divaricata Root on the Colon Cancer Cells Caco-2
}

\author{
Magdalena Matusiewicz ${ }^{1, *}$, Katarzyna Barbara Bączek ${ }^{2}{ }^{\oplus}$, Iwona Kosieradzka ${ }^{1}$, \\ Tomasz Niemiec $^{1}{ }^{1}$, Marta Grodzik ${ }^{1}{ }^{1}$, Jarosław Szczepaniak ${ }^{1}{ }^{\circledR}$, Sylwia Orlińska ${ }^{1}$ \\ and Zenon Węglarz ${ }^{2}$
}

1 Department of Animal Nutrition and Biotechnology, Faculty of Animal Sciences, Warsaw University of Life Sciences, Ciszewskiego 8, 02-786 Warsaw, Poland; iwona_kosieradzka@sggw.pl (I.K.); tomasz_niemiec@sggw.pl (T.N.); marta_grodzik@sggw.pl (M.G.); jaroslaw_szczepaniak@sggw.pl (J.S.); sylwia.orzelek@gmail.com (S.O.)

2 Laboratory of New Herbal Products, Department of Vegetable and Medicinal Plants, Faculty of Horticulture, Biotechnology and Landscape Architecture, Warsaw University of Life Sciences, Nowoursynowska 159, 02-776 Warsaw, Poland; katarzyna_baczek@sggw.pl (K.B.B.); zenon_weglarz@sggw.pl (Z.W.)

* Correspondence: magdalena_matusiewicz@sggw.pl; Tel.: +48-692-628-961

Received: 14 August 2019; Accepted: 9 September 2019; Published: 12 September 2019

\begin{abstract}
Colorectal cancer ranks 3rd in terms of cancer incidence. Growth and development of colon cancer cells may be affected by juice and extracts from Saposhnikovia divaricata root. The objective of the research was to analyze the effect of $S$. divaricata juice and extracts on the viability, membrane integrity and types of cell death of Caco-2 cells. Juice and extracts were analyzed using Ultra-High Performance Liquid Chromatography-Mass Spectrometry (UHPLC-MS) and in respect of the presence of antioxidants, total carbohydrates, protein, fat and polyphenols. The contents of cimifugin $\beta$-D-glucopyranoside, cimifugin, 4'-O-glucopyranosyl-5-O-methylvisamminol, imperatorin and protein were the highest in juice. 50\% Hydroethanolic extract had the greatest antioxidant potential, concentration of polyphenols and fat. Water extract was characterized by the highest content of glutathione. Juice and $75 \%$ hydroethanolic extract contained the most carbohydrates. After the application of juice, $50 \%$ extract and the juice fraction containing the molecules with molecular weights $>50 \mathrm{kDa}$, a decrease of the cell viability was noted. Juice and this extract exhibited the protective properties in relation to the cell membranes and they induced apoptosis. The knowledge of further mechanisms of anticancer activity of the examined products will allow to consider their use as part of combination therapy.
\end{abstract}

Keywords: Saposhnikovia divaricata; juice; extract; chemical composition; colon cancer; viability; apoptosis

\section{Introduction}

Globally colorectal cancer ranks 3rd in terms of cancer incidence and 2nd in terms of mortality [1]. The incidence rates of this disease in transition countries are over 3-fold higher than in transitioning countries and the mortality rates are over 2 -fold higher. The highest incidence rates of colon cancer were noted in European countries, Australia and New Zealand, North America, eastern Asia and Uruguay.

The predisposition to the development of colorectal cancer is hereditary, with a risk of about $12-35 \%$ attributed to the genetic factors [2]. The increase in colorectal cancer incidence is related to the effects of dietary patterns, obesity and lifestyle factors and the risk of this cancer can be reduced through proper dietary habits and lifestyle $[2,3]$. 
Current treatment of colorectal cancer is based on surgery with or without chemotherapy and/or radiotherapy, before or after surgery [4]. However, this treatment is not always effective because of the development of recurrent disease in $30 \%$ of patients with stage I-III colorectal cancer and up to $65 \%$ of patients with stage IV [5]. The adverse effects of this therapy impair the patient's life quality and may negatively affect the treatment course, outcome and costs [2].

A promising approach in minimizing the adverse effects of conventional therapy could be the combination therapy using both a conventional chemotherapeutics or radiotherapy and natural compound(s) with significant pharmacological effects derived from plant, marine or microorganism sources $[2,4,6]$. The combination therapy targets multiple metabolic pathways using different mechanisms to decrease the development of resistance to anticancer drugs, increasing the sensitivity to the action of the chemotherapeutics [7]. Recent studies have highlighted the importance of combination therapy and consider it more effective compared to conventional chemotherapeutic agents [8]. Some natural compounds are able to modulate signaling pathways and the expression of genes associated with cell proliferation, differentiation, apoptosis, angiogenesis and metastasis [9].

In Chinese and Japanese traditional medicine, the underground organs of Saposhnikovia divaricata (Turcz.) Schischk. (Apiaceae) have been used as one of the most important drugs [10]. The species grows wild in north-eastern China and Inner Mongolia [11,12]. Saposhnikoviae Radix is officially listed in the pharmacopoeias of China, Japan and Korea and is also one of the candidates for inclusion in the German Pharmacopoeia (DAB) [13,14].

Extracts from this raw material have been used for the treatment of common cold, adiaphoresis, cough, allergic rhinitis, headache, migraine, dizziness as well as in rheumatic disorders, arthralgia, diarrhea, smallpox and anxiety in children [10,15-17]. They have demonstrated anti-inflammatory, anti-pyretic, anti-convulsant activities and inhibitory effects on peptic ulcers. Antimicrobial, antiviral, antioxidant and antiproliferative activities were also mentioned [10,18].

Two compounds, cimifugin $\beta$-D-glucopyranoside and 4'-O-glucopyranosyl-5-O-methyl-visamminol, are considered to be mainly responsible for the activity of this raw material. These chromones were selected as reference compounds in the identification and quality assessment of Saposhnikoviae Radix. According to the Chinese Pharmacopoeia (2010) [19], the raw material (dry matter) should contain not less than $0.24 \%$ of both compounds. Aside from chromones, Saposhnikoviae Radix is rich in coumarins, furanocoumarins, polyacetylenes and polysaccharides. It also contains some phenolics, acid esters and a small amount of essential oil, with caryophyllene oxide, sabinene and $\beta$-pinene as dominant compounds [15,20-22].

Cimifugin, a coumarin abundant in S. divaricata roots, exerts analgesic effects [20]. This effect was also confirmed for 4'-O-glucopyranosyl-5-O-methylvisamminol and cimifugin $\beta$-D-gluco-pyranoside, as well as antipyretic, anti-platelet aggregation and anti-inflammatory actions [23]. Cimifugin $\beta$-D-glucopyranoside and cimifugin appear to inhibit major inflammatory pathways, nuclear factor (NF)-KB, cAMP response element-binding protein (CREB), mitogen activated protein kinases (MAPKs) and nitric oxide production $[15,24]$. The rate of inhibition of the production of NO in lipopolysaccharide (LPS)-activated RAW264.7 macrophages by cimifugin $\beta$-D-glucopyranoside was lower than by cimifugin, its deglucosylated biotransformation product, formed as a result of incubation with human intestinal flora [25]. 4'-O-Glucopyranosyl-5-O-methylvisamminol, cimifugin $\beta$-D-glucopyranoside and cimifugin are the inhibitors of matrix metalloproteases (MMP)-2, involved in the occurrence and development of inflammatory reactions, tissue remodeling, wound healing and cancer. 4'-O-Glucopyranosyl-5-O-methylvisamminol turned out to be the strongest inhibitor [26].

The furanocoumarin imperatorin, an important constituent of $S$. divaricata root, exhibits many pharmacological properties, including anticancer, anti-inflammatory, anti-osteoporotic, myorelaxant, hepatoprotective, antibacterial and antiviral activities, in addition to a beneficial influence on the cardiovascular and central nervous system [27]. Imperatorin is contained in many traditional drugs, especially in Traditional Chinese Medicine. 
Considering the above multidirectional health-promoting properties of the root of S. divaricata, including anticancer activities, the juice and extracts derived from it, containing chemical compounds possessing potential anticancer properties, may affect growth and development of colon cancer cells. The objective of this research was to analyze the chemical composition of juice and water, $50 \%$ and $75 \%$ hydroethanolic extracts from the root of S. divaricata, as well as to determine their redox properties. Then, the effect of juice and extracts on the viability of Caco- 2 human colorectal adenocarcinoma cells was evaluated. Moreover, the influence of fractions of juice and 50\% hydroethanolic extract, containing components of different molecular weights, on Caco-2 cell viability was examined. Finally, the effect of juice and 50\% hydroethanolic extract on the membrane integrity and types of cell death was determined.

\section{Results}

\subsection{Content of Cimifugin $\beta$-D-glucopyranoside, Cimifugin, 4'-O-Glucopyranosyl-5-O-methylvisamminol} and Imperatorin

The contents of the examined bioactive compounds were by far the highest in juice (Figure 1). The contents of cimifugin $\beta$-D-glucopyranoside (Figure 1a), 4'-O-glucopyranosyl-5-O-methyl-visamminol (Figure 1c) and imperatorin (Figure 1d) in 75\% hydroethanolic extract were statistically significantly lower than in juice, but significantly higher than in 50\% extract. Concentrations of these bioactives were significantly the smallest in water extract. Water extract contained significantly less cimifugin than juice but significantly more compared to both hydroethanolic extracts (Figure 1b).

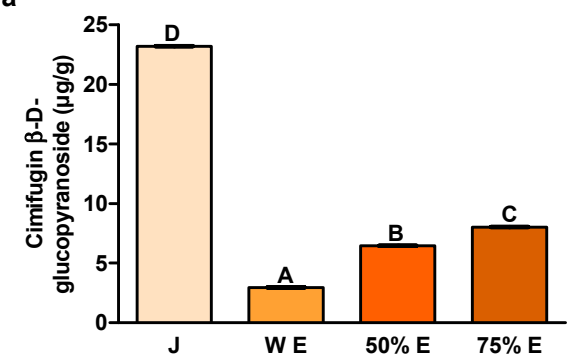

c

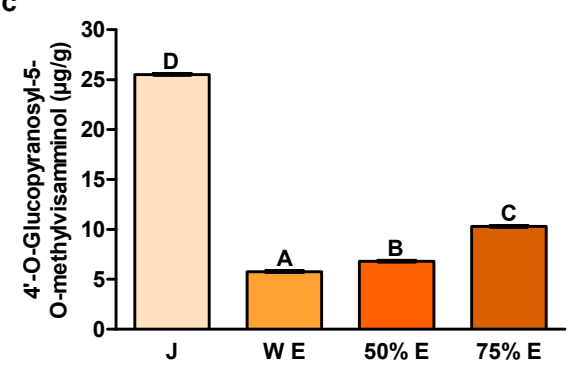

b

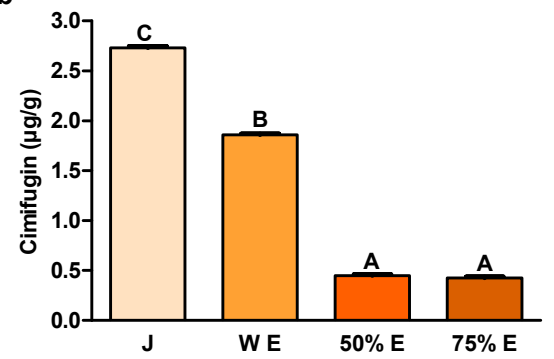

d

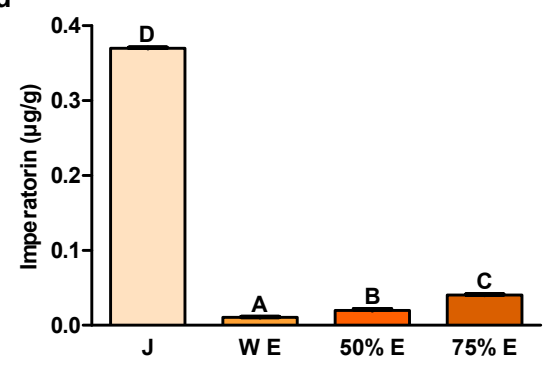

Figure 1. Content of (a) cimifugin $\beta$-D-glucopyranoside; $\quad$ (b) cimifugin; (c) 4'-O-glucopyranosyl-5-O-methylvisamminol and (d) imperatorin in juice (J), water extract (W E), 50\% hydroethanolic extract (50\% E) and 75\% hydroethanolic extract (75\% E) from Saposhnikovia divaricata root. Error bars indicate standard error of the mean. Statistically significant effect: values of one compound without common superscript $(\mathrm{A}, \mathrm{B}, \mathrm{C}, \mathrm{D})$ are significantly different $(p<0.01) . n=3$.

\subsection{Redox State Indicators}

In the current study, the ferric-reducing antioxidant power of $50 \%$ and $75 \%$ hydroethanolic extracts was significantly greater than in water extract and its value was the lowest in juice (Figure 2a). Scavenging activities of $2.2^{\prime}$-azino-bis(3-ethylbenzthiazoline-6-sulfonic acid) radical cation (ABTS.+ ${ }^{+}$) 
and 2.2-diphenyl-1-picrylhydrazyl radical (DPPH.) by 50\% hydroethanolic extract were significantly higher than by $75 \%$ extract (Figure $2 b, c$ ). Scavenging activities of ABTS. ${ }^{+}$and DPPH. by $75 \%$ extract were significantly greater than by water extract. Significantly the lowest values of this redox state indicators were noted for juice. Significantly the highest content of glutathione (GSH) was found in water extract and the lowest in juice (Figure 2d).
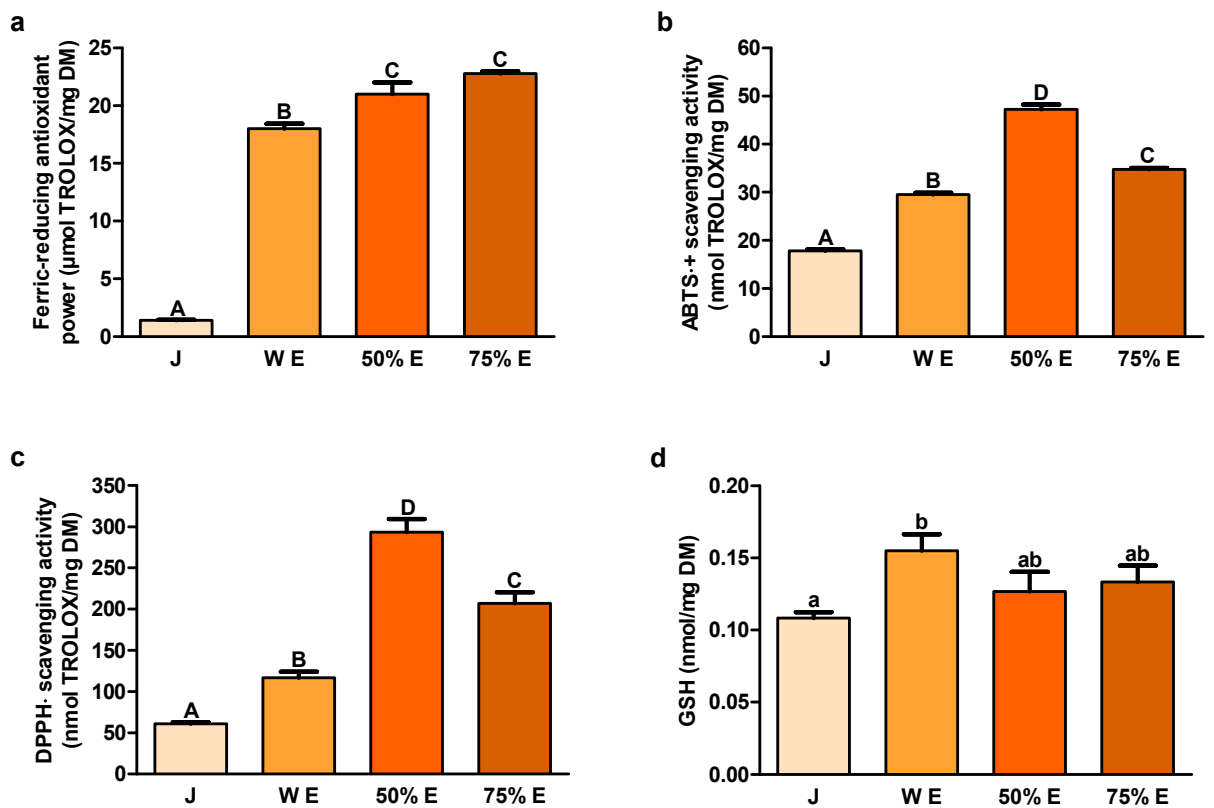

Figure 2. Indicators of redox state: (a) ferric-reducing antioxidant power; (b) ABTS. ${ }^{+}$ (2.2'-azino-bis(3-ethylbenzthiazoline-6-sulfonic acid) radical cation) scavenging activity; (c) DPPH. (2.2-diphenyl-1-picrylhydrazyl radical) scavenging activity and (d) GSH (glutathione) in juice (J), water extract (W E), 50\% hydroethanolic extract (50\% E) and 75\% hydroethanolic extract (75\% E) from Saposhnikovia divaricata root. Error bars indicate standard error of the mean. Statistically significant effect: values of one indicator without common superscript are significantly different $(\mathrm{a}, \mathrm{b}-\mathrm{at}$ a significance level of $p<0.05 ; \mathrm{A}, \mathrm{B}, \mathrm{C}, \mathrm{D}$ - at a significance level of $p<0.01$ ). $n=6$ (Figure 2a,c,d), $n=5$ (Figure 2b). DM-dry matter.

\subsection{Content of Total Carbohydrates, Protein and Fat}

The data showed that juice and extracts consisted mostly of total carbohydrates, the content of which was statistically significantly the highest in $75 \%$ hydroethanolic extract and juice and significantly the lowest in 50\% extract (Table 1). Furthermore, the extracts scarcely contained total protein, whereas juice contained about $5 \%$. The total fat content was significantly higher in $50 \%$ hydroethanolic extract than in juice.

Table 1. Concentration of total carbohydrates, protein and fat and polyphenols in juice (J), water extract (W E), 50\% hydroethanolic extract (50\% E) and 75\% hydroethanolic extract (75\% E) from Saposhnikovia divaricata $\operatorname{root}^{1}$.

\begin{tabular}{|c|c|c|c|c|c|}
\hline Compound & $\mathbf{J}$ & W E & $50 \% \mathrm{E}$ & $75 \% \mathrm{E}$ & $p$ \\
\hline $\begin{array}{c}\text { Total carbohydrates } \\
\text { (\% DM) }\end{array}$ & $71.76 \pm 1.72 \mathrm{BC}$ & $64.64 \pm 3.04^{B}$ & $47.87 \pm 0.72{ }^{\mathrm{A}}$ & $77.92 \pm 1.52^{\mathrm{C}}$ & $<0.0001$ \\
\hline Total protein $(\% \mathrm{DM})$ & $5.13 \pm 0.40^{B}$ & $0.21 \pm 0.02^{\mathrm{A}}$ & $0.75 \pm 0.00^{\mathrm{A}}$ & $<0.1$ & $<0.0001$ \\
\hline Total fat (\% DM) & $5.44 \pm 0.11^{\mathrm{A}}$ & ND & $14.90 \pm 0.00^{B}$ & ND & 0.0001 \\
\hline $\begin{array}{c}\text { Polyphenols } \\
\text { ( } \mu \mathrm{g} \text { quercetin/mg DM) }\end{array}$ & $25.31 \pm 0.14^{\mathrm{A}}$ & $50.36 \pm 0.16^{\mathrm{B}}$ & $84.14 \pm 0.16^{\mathrm{D}}$ & $66.68 \pm 0.28^{C}$ & $<0.0001$ \\
\hline
\end{tabular}

${ }^{1}$ Data are expressed as mean \pm standard error of the mean. Statistically significant effect: values of one parameter without common superscript $(\mathrm{A}, \mathrm{B}, \mathrm{C}, \mathrm{D})$ are significantly different $(p<0.01) . \quad n=3$ (total carbohydrates and polyphenols), $n=6$ (total protein), $n=2$ (total fat). ND—not determined, DM-dry matter. 


\subsection{Concentration of Polyphenols}

The content of polyphenols was statistically significantly the highest in 50\% hydroethanolic extract (Table 1). $75 \%$ Extract contained significantly less polyphenols than $50 \%$ extract and significantly more than water extract. Polyphenol concentration was significantly the lowest in juice.

\subsection{Effect of Juice and Extracts on Cell Viability}

The effect of different concentrations of juice and extracts on the viability of Caco-2 cells was assessed by a methylthiazolyldiphenyl-tetrazolium bromide (MTT) test, based on the oxidative activity of the mitochondria of live cells. The results of the 24-h assay demonstrated that three concentrations of juice (10,1 and $0.1 \mathrm{mg} / \mathrm{mL})$ and $50 \%$ hydroethanolic extract $(1,0.1$ and $0.01 \mathrm{mg} / \mathrm{mL})$ statistically significantly reduced cell viability (Figure 3a). The concentration of $0.1 \mathrm{mg} / \mathrm{mL}$ of juice and $50 \%$ extract was found to be effective in decreasing cell viability also in the 72-h assay (Figure $3 b$ ). No reduction of cell viability was observed after the application of water and $75 \%$ extracts.

a

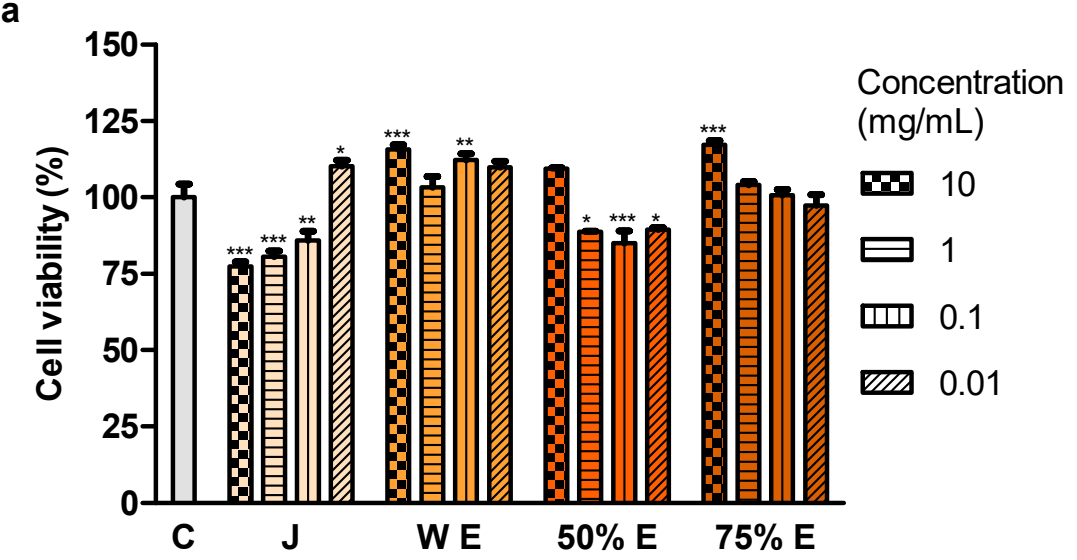

b

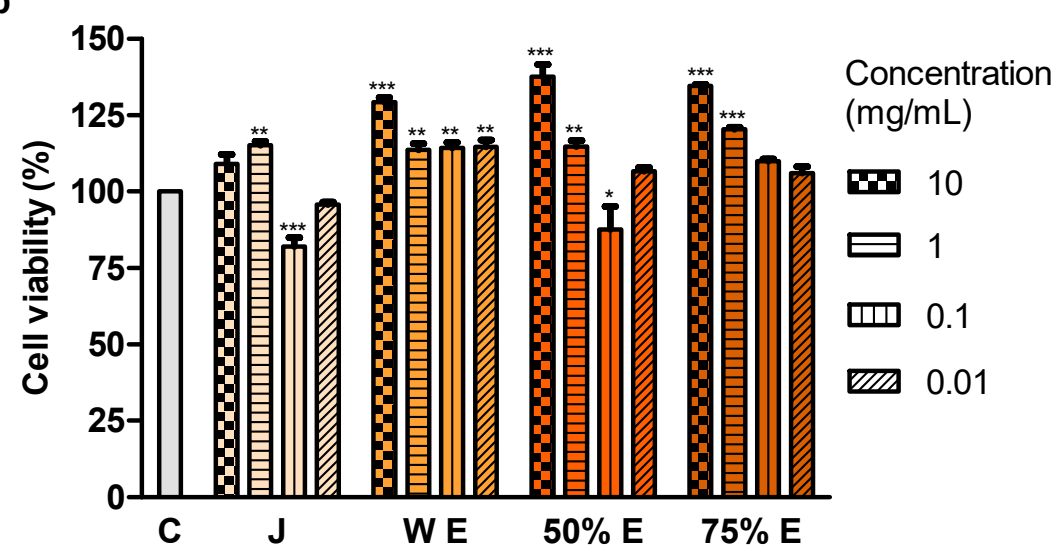

Figure 3. Viability of Caco-2 cells after (a) $24 \mathrm{~h}$ and (b) $72 \mathrm{~h}$ of treatment with juice (J), water extract (W E), 50\% hydroethanolic extract (50\% E) and 75\% hydroethanolic extract (75\% E) from Saposhnikovia divaricata root, at different concentrations. C-control cells (treated with deionized water). Error bars indicate standard error of the mean. Statistically significant effect: * represents values that differ from control at $p<0.05,{ }^{* *}$ represents values that differ from control at $p<0.01,{ }^{* * *}$ represents values that differ from control at $p<0.001 . n=5$.

\subsection{Effect of Fractions of Juice and 50\% Hydroethanolic Extract on Cell Viability}

24-h test revealed that the molecules of molecular weight $>50 \mathrm{kDa}$ of juice (at the concentrations of 15.9 and $15.9 \times 10^{-1} \mathrm{mg} / \mathrm{mL}$ ) decreased the viability of Caco-2 cells in a statistically significant manner 
(Figure 4a). The remaining fractions, containing particles of molecular weights $10-50 \mathrm{kDa}, 3-10 \mathrm{kDa}$ and $<3 \mathrm{kDa}$, as well as fractions of $50 \%$ hydroethanolic extract did not show this effect (Figure $4 \mathrm{a}, \mathrm{b}$ ).
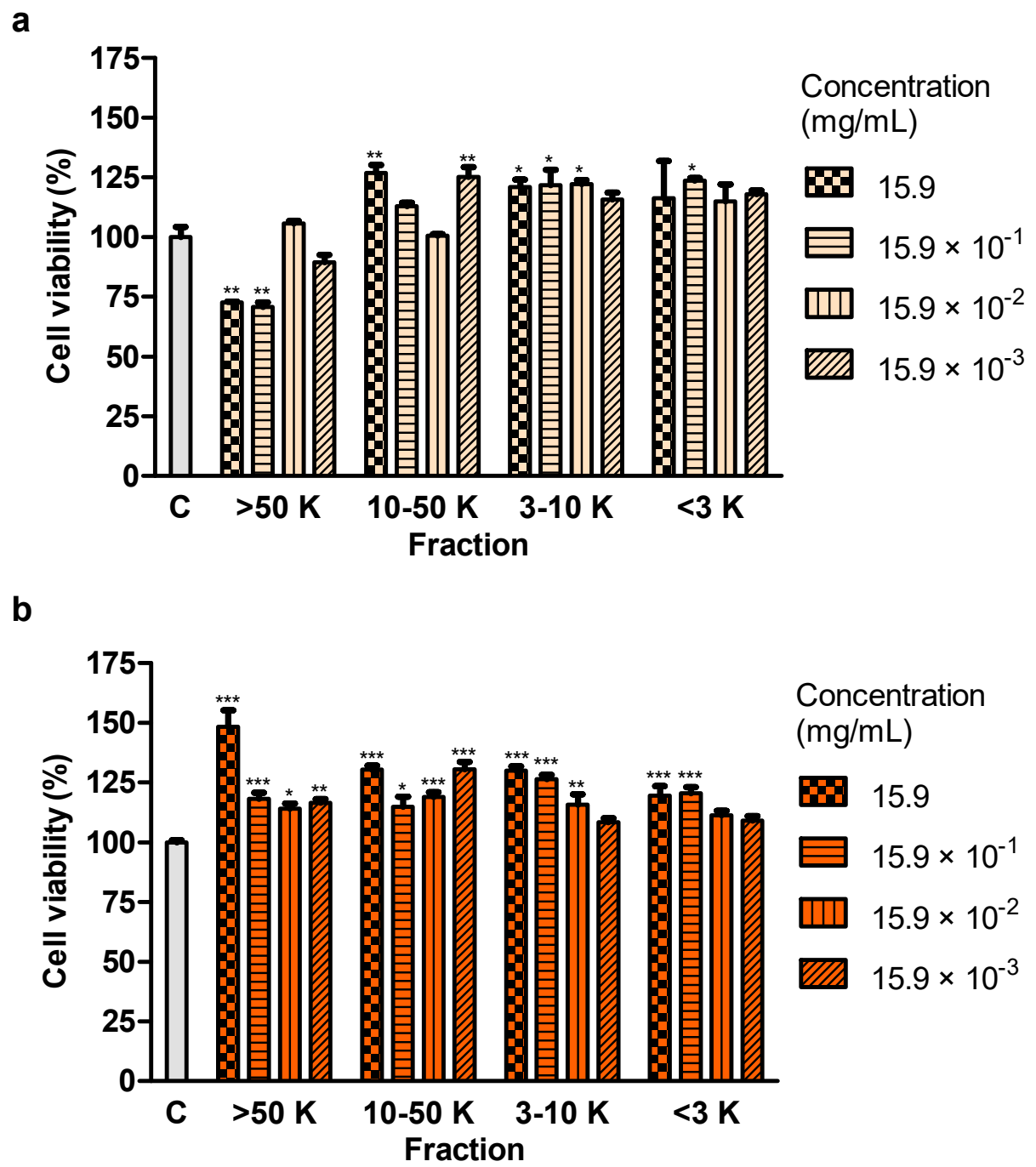

Figure 4. Viability of Caco-2 cells after treatment for $24 \mathrm{~h}$ with fractions $>50 \mathrm{kDa}(>50 \mathrm{~K}), 10-50 \mathrm{kDa}$ $(10-50 \mathrm{~K}), 3-10 \mathrm{kDa}(3-10 \mathrm{~K})$ and $<3 \mathrm{kDa}(<3 \mathrm{~K})$ of (a) juice and (b) 50\% hydroethanolic extract from Saposhnikovia divaricata root, at different concentrations. C-control cells (treated with deionized water). Error bars indicate standard error of the mean. Statistically significant effect: ${ }^{*}$ represents values that differ from control at $p<0.05,{ }^{* *}$ represents values that differ from control at $p<0.01,{ }^{* * *}$ represents values that differ from control at $p<0.001 . n=5$.

\subsection{Effect of Juice and 50\% Hydroethanolic Extract on Cell Membrane Integrity}

The integrity of cell membranes after the application of juice and $50 \%$ hydroethanolic extract was examined based on the release of the cytosolic enzyme-lactate dehydrogenase (LDH) from damaged cells. LDH activity did not change statistically significantly after the treatment of the cells with juice and $50 \%$ extract for $24 \mathrm{~h}$ (Figure 5a). Some concentrations of juice (from $15.9 \times 10^{-2}$ to $15.9 \times 10^{-5} \mathrm{mg} / \mathrm{mL}$ ) and $50 \%$ extract $\left(15.9 \times 10^{-1}\right.$ and $\left.15.9 \times 10^{-4} \mathrm{mg} / \mathrm{mL}\right)$ significantly reduced LDH activity after the treatment for $72 \mathrm{~h}$ (Figure $5 \mathrm{~b}$ ). 

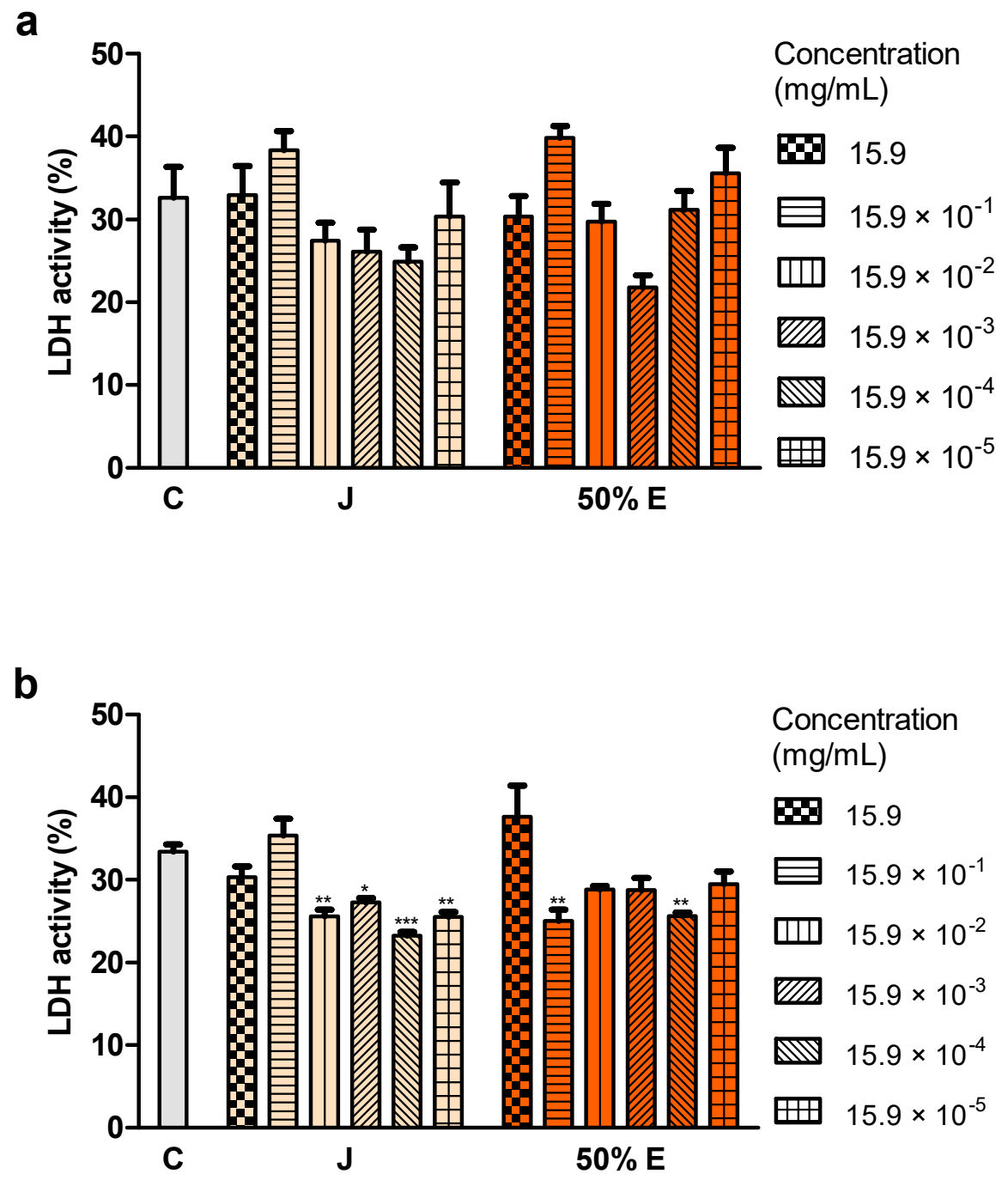

Figure 5. Integrity of membranes of Caco-2 cells after (a) $24 \mathrm{~h}$ and (b) $72 \mathrm{~h}$ of treatment with juice (J) and $50 \%$ hydroethanolic extract $(50 \%$ E) from Saposhnikovia divaricata root, at different concentrations. $\mathrm{C}$ - control cells (treated with deionized water), $\mathrm{LDH}$-lactate dehydrogenase. Error bars indicate standard error of the mean. Statistically significant effect: * represents values that differ from control at $p<0.05,{ }^{* *}$ represents values that differ from control at $p<0.01{ }^{* * *}$ represents values that differ from control at $p<0.001$. $n=6$.

\subsection{Effect of Juice and 50\% Hydroethanolic Extract on Types of Cell Death}

Incubation of Caco-2 cells with juice and $50 \%$ hydroethanolic extract $\left(15.9 \times 10^{-1} \mathrm{mg} / \mathrm{mL}\right)$ statistically significantly increased the number of early apoptotic cells in the 24-h test (Figure 6). Treatment with $50 \%$ extract $\left(15.9 \times 10^{-2} \mathrm{mg} / \mathrm{mL}\right)$ significantly reduced the number of live cells in the 72-h test (Figure 7). 
A

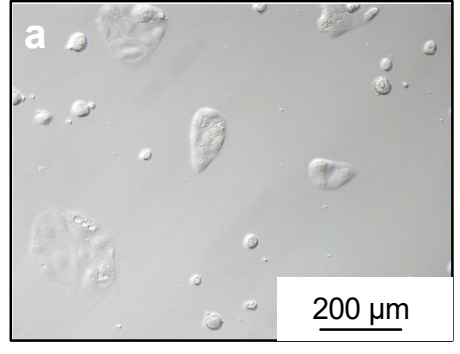

C

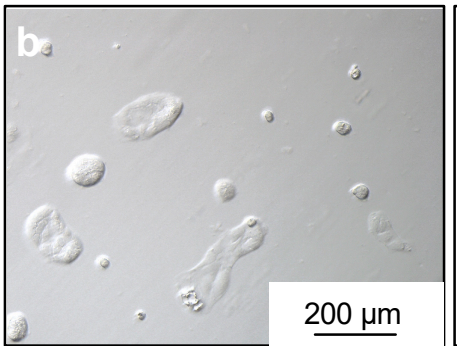

J

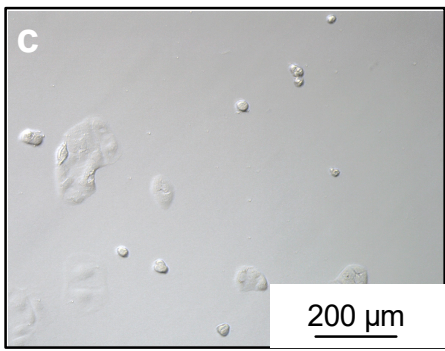

$50 \% \mathrm{E}$

B

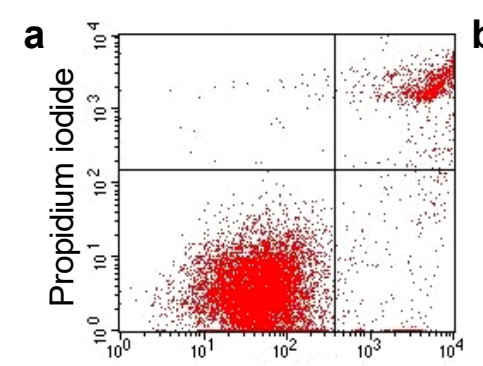

Alexa Fluor ${ }^{\circledR} 488$ Annexin V

C

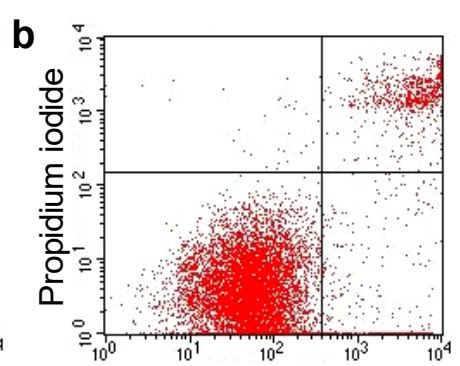

Alexa Fluor ${ }^{\circledR} 488$ Annexin V

$\mathbf{J}$

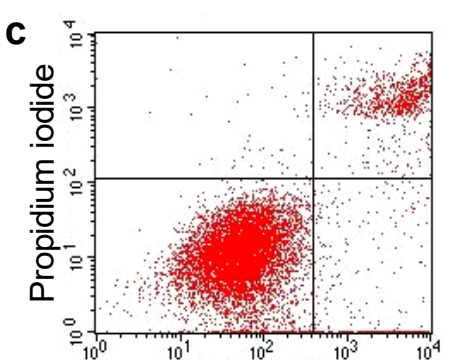

Alexa Fluor ${ }^{\circledR} 488$ Annexin V

$50 \% \mathrm{E}$

C

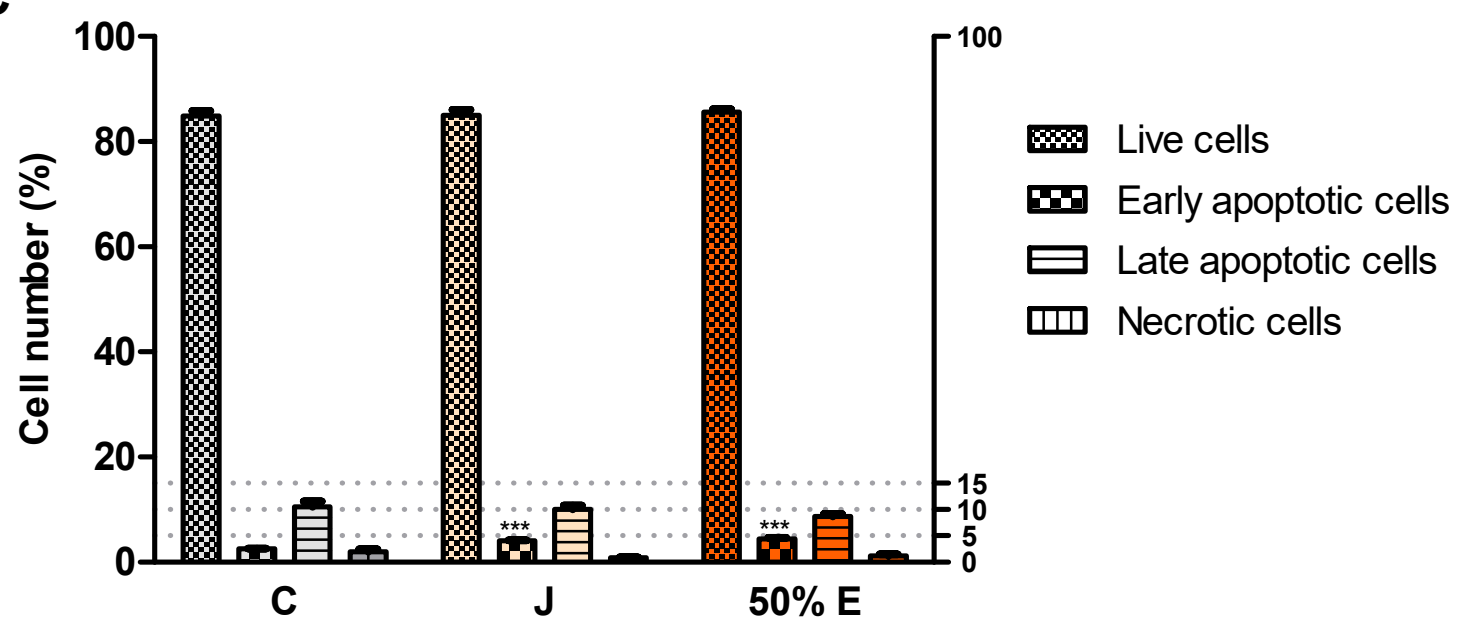

Figure 6. Types of death of Caco-2 cells after $24 \mathrm{~h}$ of treatment with juice (J) and $50 \%$ hydroethanolic extract ( $50 \%$ E) from Saposhnikovia divaricata root, at the concentration of $15.9 \times 10^{-1} \mathrm{mg} / \mathrm{mL}$. C-control cells (treated with deionized water). Panel (A) —images from light microscope, panel (B) — exemplary flow cytometry charts (lower left quadrant-live cells, lower right quadrant-early apoptotic cells, upper right quadrant-late apoptotic cells, upper left quadrant-necrotic cells), panel (C) - graphs with error bars indicating standard error of the mean. Statistically significant effect: ${ }^{* * *}$ represents values that differ from control at $p<0.001 . n=6$. 
A

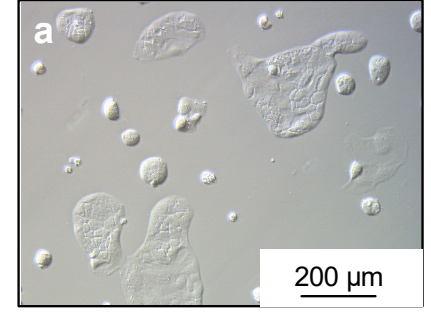

C

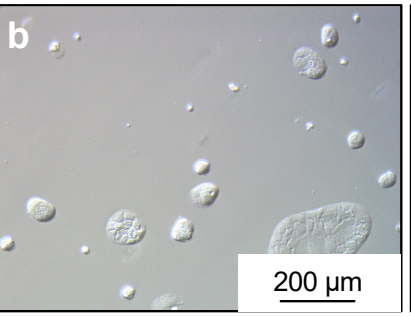

$\mathbf{J}$

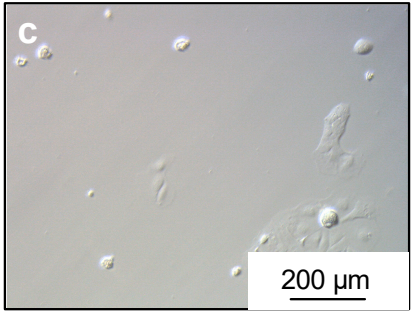

$50 \% \mathrm{E}$

B

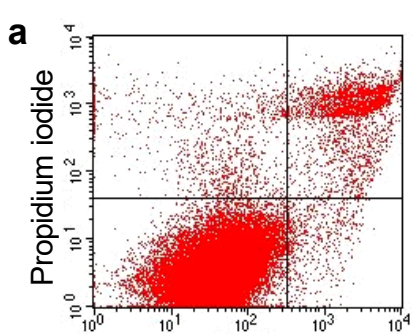

Alexa Fluor ${ }^{\circledR} 488$ Annexin V

C

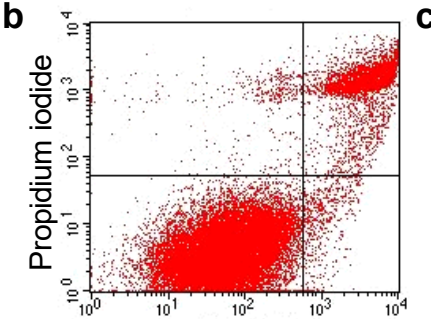

Alexa Fluor ${ }^{\circledR} 488$ Annexin V

J

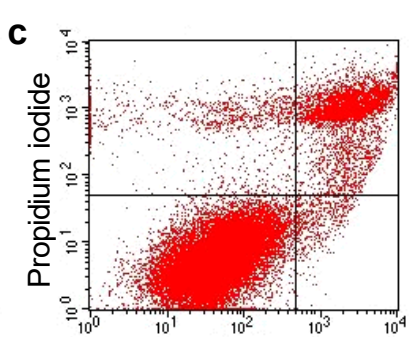

Alexa Fluor ${ }^{\circledR} 488$ Annexin V $50 \% \mathrm{E}$

\section{C}

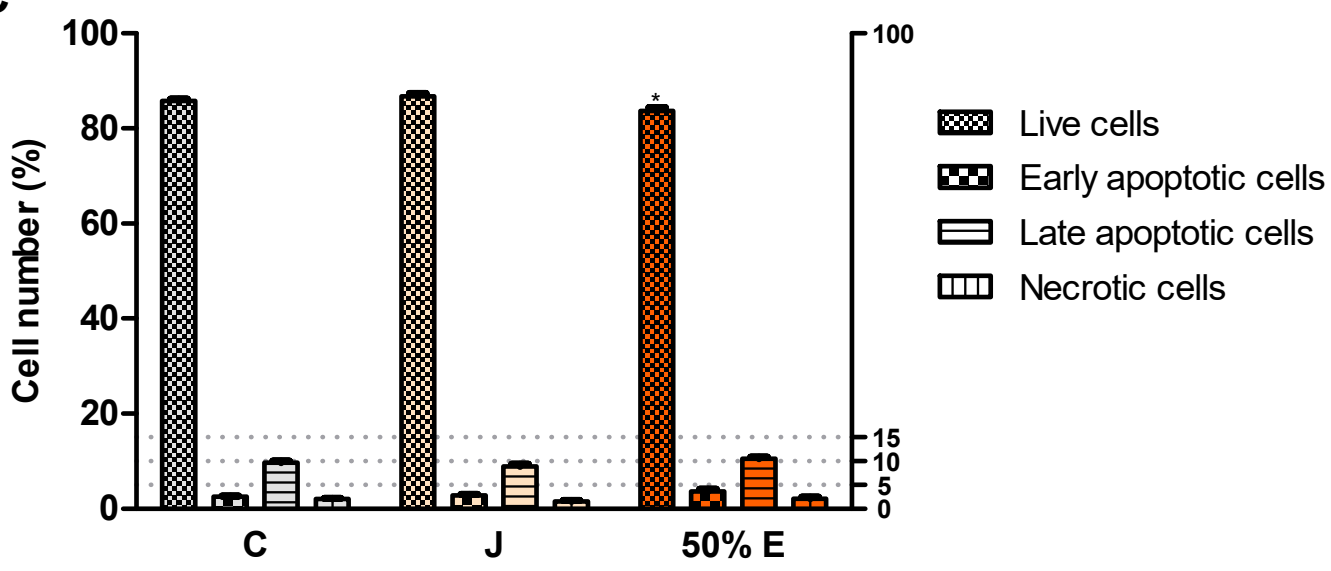

Figure 7. Types of death of Caco-2 cells after $72 \mathrm{~h}$ of treatment with juice (J) and $50 \%$ hydroethanolic extract $\left(50 \%\right.$ E) from Saposhnikovia divaricata root, at the concentration of $15.9 \times 10^{-2} \mathrm{mg} / \mathrm{mL}$. C-control cells (treated with deionized water). Panel (A)—images from light microscope, panel (B)-exemplary flow cytometry charts (lower left quadrant-live cells, lower right quadrant-early apoptotic cells, upper right quadrant-late apoptotic cells, upper left quadrant-necrotic cells), panel (C)-graphs with error bars indicating standard error of the mean. Statistically significant effect: * represents values that differ from control at $p<0.05 . n=6$.

\section{Discussion}

The content of cimifugin $\beta$-D-glucopyranoside, one of the main $S$. divaricata chromones, turned out to be the highest in juice. Its content in $75 \%$ hydroethanolic extract was much lower than in juice and higher than in other extracts. The anticancer activity of this compound was confirmed in the in vitro studies.

According to Zhang et al., cimifugin $\beta$-D-glucopyranoside, at concentrations equal to or higher than $10 \mu \mathrm{M}(4.68 \mu \mathrm{g} / \mathrm{mL})$, decreased the viability of Jurkat and J45.01 acute T cell leukemia cells, after $24 \mathrm{~h}$ and $48 \mathrm{~h}$ of treatment [28]. Jurkat cells incubated with this compound, at the concentrations of $20 \mu \mathrm{M}(9.37 \mu \mathrm{g} / \mathrm{mL})$ and $40 \mu \mathrm{M}(18.74 \mu \mathrm{g} / \mathrm{mL})$, for $24 \mathrm{~h}$ and $48 \mathrm{~h}$, underwent apoptosis. The number of early and late apoptotic cells increased with the increase of dose applied and the extension of time of treatment. Moreover, cimifugin $\beta$-D-glucopyranoside may induce apoptosis by the activation of the 
caspase pathway. The results suggest that this compound blocked the cell cycle at the G2/M phase. After the incubation with $20 \mu \mathrm{M}(9.37 \mu \mathrm{g} / \mathrm{mL})$ cimifugin $\beta$-D-glucopyranoside, for $48 \mathrm{~h}$, about $40 \%$ of cells were arrested at the G2/M phase of the cell cycle. In case of the treatment with $40 \mu \mathrm{M}(18.74 \mu \mathrm{g} / \mathrm{mL})$ cimifugin $\beta$-D-glucopyranoside, the number of cells at the G2/M phase was $56 \%$, whereas only $16.7 \%$ of control cells were at this phase. This chromone may function as the inhibitor of $\beta$-tubulin and tubulin polymerization that leads to cell cycle arrest at the G2/M phase. In the study of Huyen et al., cimifugin $\beta$-D-glucopyranoside, isolated from the $70 \%$ hydroethanolic extract from the rhizome of Cimicifuga dahurica (Turcz.) Maxim. (Ranunculaceae), at the concentration of $10 \mu \mathrm{M}(4.68 \mu \mathrm{g} / \mathrm{mL})$, showed significant antiproliferative effect on MCF-7 breast cancer cells exposed to a proliferation stimulator [29].

The content of cimifugin, the other chromone of $S$. divaricata root, was the highest in juice. Among the extracts, the highest content of this compound was noted in the water extract. Yokosuka et al. showed that the methanolic extract from the root and rhizome of $S$. divaricata decreased the viability of HL-60 human acute promyelocytic leukemia cells, after $72 \mathrm{~h}$ of treatment [22]. Furthermore, six chromone derivatives ( $3^{\prime}$-O-angeloyhamaudol, ledebouriellol, divaricatol, cimifugin, sec-O-glucosylhamaudol and 5-O-methylvisammioside) and five polyacetylene derivatives were isolated from the methanolic extract. The first three chromone derivatives decreased the viability of HL-60 cells, however, there was no effect in case of the last three, including cimifugin.

The results suggest that the cells exposed to 3 -O-angeloyhamaudol underwent apoptosis. The results indicate that this compound, by the loss of the mitochondrial membrane potential, induced the cytochrome $\mathrm{c}$ release from the space between the mitochondrial membranes into the cytosol. In the cytosol, cytochrome c interacted with Apaf-1 (apoptotic protease-activating factor-1) and the complex of these proteins activated caspase-9, which activated caspase-3. However, the treatment of MCF-7 cells with the extract from Cimicifuga foetida L. (Ranunculaceae), containing cimifugin and cimifugin glucoside, resulted in the reduction of cell number [30]. Moreover, this extract diminished the expression of mRNA of heat shock protein 27, which content is increased in different human cancers and which exhibits cytoprotective activity, affecting tumorigenesis and tumor susceptibility to treatment.

The content of the second main S. divaricata chromone-4'-O-glucopyranosyl-5-O-methyl-visamminol, like cimifugin $\beta$-D-glucopyranoside, was by far the highest in juice. Among the extracts, the greatest concentration of this compound was also contained in $75 \%$ hydroethanolic extract. In the research of Ma et al., 4'-O-glucopyranosyl-5-O-methylvisamminol and four other chromone glycosides isolated from the $70 \%$ hydroethanolic extract from the root of $S$. divaricata, decreased the viability of three cancer cell lines: PC-3 human Caucasian prostate adenocarcinoma, SK-OV-3 human ovarian carcinoma and H460 human lung carcinoma [31].

The content of imperatorin, belonging to the furanocoumarins, was also by far the largest in juice from the root of $S$. divaricata. Its content in $75 \%$ hydroethanolic extract was also higher compared to other extracts. Numerous in vitro and in vivo studies have demonstrated the anticancer properties of imperatorin and its potential mechanisms of action. Imperatorin isolated from the extract from the medicinal plant Angelica dahurica (Fisch. ex Hoffm.) Benth. et Hook. f. ex Franch. et Sav. (Apiaceae) significantly decreased the viability of HCT-15 human colorectal adenocarcinoma, A549 human non-small cell lung cancer, SK-OV-3 human Caucasian ovary adenocarcinoma, SK-MEL-2 human malignant melanoma and XF498 human central nervous system cancer cells, after $48 \mathrm{~h}$ of treatment [32]. In turn, imperatorin separated from the $85 \%$ methanolic fraction from Glehnia littoralis F. Schmidt ex Miq. (Apiaceae), at the concentrations of 1,10 and $100 \mu \mathrm{M}(0.27,2.70$ and $27.03 \mu \mathrm{g} / \mathrm{mL}$, respectively), exhibited dose-dependent decrease of the viability of HT-29 human colorectal adenocarcinoma cells, after $48 \mathrm{~h}$ of treatment [33]. Moreover, after this time of incubation, it reduced the expression of mRNA of B-cell lymphoma-2 (Bcl-2), an intracellular suppressor of apoptosis. Imperatorin decreased also the expression of mRNA of inducible nitric oxide synthase (iNOS) and cyclooxygenase-2 (COX-2), proinflammatory enzymes related to the pathophysiology of many chronic diseases and 
cancers. Furthermore, imperatorin from trifoliate orange, Poncirus trifoliata (L.) Raf. (Rutaceae), at the concentrations of 74 and $740 \mathrm{nmol} / \mathrm{mL}(20.00$ and $200.01 \mu \mathrm{g} / \mathrm{mL})$, decreased the viability of HCT-15 human colorectal adenocarcinoma cells and, at the concentrations of $7.4,74$ and $740 \mathrm{nmol} / \mathrm{mL}$ (2.00, 20.00 and $200.01 \mu \mathrm{g} / \mathrm{mL}$, respectively), reduced the viability of SNU-449 human hepatocellular carcinoma cells, after 4 days of treatment [34]. The results suggest that after this time of treatment, with the concentrations of 74 and $740 \mathrm{nmol} / \mathrm{mL}(20.00$ and $200.01 \mu \mathrm{g} / \mathrm{mL})$, it induced apoptosis. Moreover, imperatorin, at $370 \mathrm{nmol} / \mathrm{mL}(100.00 \mu \mathrm{g} / \mathrm{mL})$ and at $740 \mathrm{nmol} / \mathrm{mL}(200.01 \mu \mathrm{g} / \mathrm{mL})$, induced the cell cycle arrest at the G1-SubG1 (apoptotic) phase, after $24 \mathrm{~h}$ of treatment. After this time, imperatorin, at the concentrations of 370 and $740 \mathrm{nmol} / \mathrm{mL}(100.00$ and $200.01 \mu \mathrm{g} / \mathrm{mL})$, upregulated the expression of Bcl-2 associated X protein (Bax), the pro-apoptotic protein and downregulated the expression of $\mathrm{Bcl}-2$, the anti-apoptotic protein. In the study of Zheng et al., imperatorin, at the concentrations of 20-200 $\mu \mathrm{M}(5.41-54.06 \mu \mathrm{g} / \mathrm{mL})$, reduced the viability of HT-29 human colorectal adenocarcinoma cells, after $24 \mathrm{~h}, 48 \mathrm{~h}$ and $72 \mathrm{~h}$ of treatment [35]. This furanocoumarin, at the concentrations of $40-200 \mu \mathrm{M}$ $(10.81-54.06 \mu \mathrm{g} / \mathrm{mL})$, did not significantly influence on the level of activity of released LDH, after $48 \mathrm{~h}$ of treatment. After this time of treatment, imperatorin, at the concentrations of 100,200 and $300 \mu \mathrm{M}(27.03$, 54.06 and $81.08 \mu \mathrm{g} / \mathrm{mL}$, respectively), induced apoptosis. This compound modulated the intrinsic apoptotic pathway, involving the caspase cascade, Bcl-2 members, p53, p21 and MDM2 (mouse double minute 2 homolog), and made considerable changes in the protein expression of caspase-8, Bax, MDM2, p53 and p21. Moreover, imperatorin, at the concentrations of 50, 100 and $150 \mu \mathrm{M}(13.51,27.03$ and $40.54 \mu \mathrm{g} / \mathrm{mL}$, respectively), induced cell cycle arrest at the G1 phase. This furanocoumarin also increased the content of reactive oxygen species (ROS) in the cells, after $24 \mathrm{~h}$ of treatment. According to Mi et al., imperatorin from the root of Angelica dahurica inhibited the activation of hypoxia-induced HIF-1 (hypoxia-inducible factor-1) [36]. It downregulated the protein expression of HIF-1 $\alpha$ and the expression of HIF target genes: vascular endothelial growth factor (VEGF) and erythropoietin, essential for tumor growth. Imperatorin suppressed the synthesis of HIF- $1 \alpha$ protein by the inhibition of the mammalian target of rapamycin (mTOR)/ribosomal protein S6 kinase (p70S6K)/eIF4E binding protein-1 (4E-BP1) and mitogen-activated protein kinase (MAPK) pathways. Moreover, this compound arrested the cell cycle at the G1 phase. It also inhibited tumor growth and blocked tumor angiogenesis in a murine xenograft model, without apparent toxicity.

The bioavailability of cimifugin $\beta$-D-glucopyranoside depends to a large extent on its biotransformation in the colon [25]. Cimifugin, as most of the examined chromones and coumarins of $S$. divaricata, turned out to be well-absorbed in the Caco-2 monolayer model, whereas cimifugin $\beta$-D-glucopyranoside was moderately absorbed [37]. The passive diffusion mechanism for these compounds was proposed. According to Li et al., cimifugin $\beta$-D-glucopyranoside exhibited low bioavailability and was rapidly eliminated after oral administration [38]. Moreover, absorption and elimination of cimifugin $\beta$-D-glucopyranoside and cimifugin in the root extract of $S$. divaricata were longer than for the single compounds, probably because of the interactions between the chemical compounds in the extract. The experiment on rats of Gao and Luan demonstrated that imperatorin is mainly absorbed in the colon [39]. The absorption mechanism may be the passive diffusion with the active transport. Well absorption in the colon of the most of the chromones and coumarins of S. divaricata and the positive influence on the absorption of the interaction between the compounds in S. divaricata extract indicate that the examined juice and extracts, after ingestion, may to a large extent influence on the colon cells, better than single compounds.

Long-term ingestion of antioxidants could decrease the colorectal cancer incidence in rats, by reducing oxidative stress [40]. These compounds could also improve the severity of colitis, the inflammatory and the preneoplastic state of the colorectal cancer, by reducing the elevated content of malondialdehyde (MDA). In our study, ferric-reducing antioxidant power, based on the electron donation by antioxidants to neutralize free radicals by forming stable products [41], was the highest for hydroethanolic extracts from the root of $S$. divaricata and the lowest for juice. Scavenging activity of ABTS ${ }^{+}$, also representing the electron transfer properties, and scavenging activity of DPPH., a stable 
free radical accepting an electron or a hydrogen to become a stable molecule, were the highest for $50 \%$ hydroethanolic extract. The values of these indices were lower for $75 \%$ hydroethanolic extract and water extract and the lowest for juice. ABTS. ${ }^{+}$scavenging activity by $70 \%$ hydroethanolic extract from the root of $S$. divaricata was demonstrated earlier by other authors [18]. Our results indicate the highest content of hydrophilic and hydrophobic antioxidants in 50\% hydroethanolic extract and the largest potential of this extract in decreasing oxidative stress in the organism.

Among the enzymatic systems responsible for the intracellular redox balance maintenance, the main role plays GSH, which participates in antioxidant defense systems and many metabolic processes [42,43]. On the other hand, elevated GSH concentrations are noted in different tumors making the cancer tissues more resistant to prooxidant therapies, including chemotherapy and radiotherapy. Enhancing the capacity of GSH to protect the cells from the changes in redox state or environmental toxins could be important as the cytoprotective strategy against cancer. On the contrary, depletion of GSH and related detoxification pathways could sensitize cancer cells to chemotherapy. In our investigation, content of GSH, as hydrophilic compound, was the highest in water extract. The lowest value of GSH was noted in juice.

In the study of Zhang et al., DPPH. scavenging activity of water and $95 \%$ hydroethanolic extracts from the root of $S$. divaricata significantly correlated with total phenolics content [44]. A similar situation was noted in the case of ABTS.+ ${ }^{+}$scavenging activity and $80 \%$ hydromethanolic extract [45]. Our results of scavenging activities of ABTS. ${ }^{+}$and DPPH. and concentration of polyphenols are in agreement with the knowledge that the content of total phenolics is major contributor to the antioxidative activity of herbs [44,45].

The content of polyphenols in the water extract was about 5.036\%. In turn, Park et al. determined in the water extract from S. divaricata the contents of individual phenolic acids and flavonoids, which have high antioxidant activities [46]. The content of phenolic acids was $1.369 \%$ and the content of flavonoids- $1.708 \%$. Among phenolic acids, phloroglucinol, coumarin, chlorogenic, gallic, caffeic, vanillic and trans-ferulic acids were quantified and among flavonoids-(-) epigallocatechin, gallocatechin and 3-hydroxyflavone. Numerous in vitro and in vivo studies showed that these polyphenols have anticancer properties. It was demonstrated that chlorogenic acid and caffeic acid decreased the viability of Caco-2 cells, arrested the cell cycle at the $S$ phase and induced apoptosis [47]. In turn, according to Hou et al., chlorogenic acid decreased the viability of human colon cancer cells, induced the production of ROS and the cell cycle arrest at the S phase [48]. In the research on rats, chlorogenic acid showed inhibitory effect on azoxymethane-induced colon carcinogenesis [49]. Chlorogenic acid inhibited also colon cancer cell-induced lung metastasis [50]. Another phenolic acid, gallic acid, showed chemopreventive effect against 1.2-dimethylhydrazine-induced colon carcinogenesis in rats [51]. Moreover, gallic acid decreased the viability of human colon cancer cells [52]. It arrested the cell cycle at the SubG1 phase, induced the generation of ROS and apoptosis. In the study of Forester et al., gallic acid decreased the viability of human colon cancer cells, arrested the cell cycle at the Go/G1 phase and activated apoptosis [53]. Caffeic acid, in turn, decreased the viability of human colon cancer cells, increased the accumulation of the cells at the SubG1 phase of the cell cycle, ROS generation and induced apoptosis [54]. Another phenolic acid, trans-ferulic acid, increased intracellular ROS content in human lung cancer cells, decreased their viability, induced moderate apoptosis and moderately inhibited the cell migration [55]. The flavonoid (-) epigallocatechin decreased the viability of human colon cancer cells and other cancer cells [56-58] and induced apoptosis [56,58]. Another flavonoid, 3-hydroxyflavone, decreased the viability of Caco-2 cells [59].

The juice and extracts from the root of $S$. divaricata consisted mainly of carbohydrates. Their content was the highest in juice and $75 \%$ hydroethanolic extract and the smallest in the $50 \%$ hydroethanolic extract. In turn, Gao et al. demonstrated that the polysaccharides of the root of $S$. divaricata consisted of eight monosaccharides-arabinose: glucose: galactose: mannose: galacturonic acid: rhamnose: ribose: fucose, in the molar ratio of: 47.70:23.69:12.06:7.86:4.42:3.10:0.71:0.45 [60]. According to Xue-Mei, the monosaccharide constituents of $S$. divaricata were galacturonic acid: arabinose: galactose: 
rhamnose, in the proportion of 4.8: 2.3:1:0.15 [61]. Moreover, Wang et al. separated from the root and rhizome of $S$. divaricata two main acidic polysaccharides [62]. The first one consisted of galacturonic acid: arabinose: galactose: rhamnose, in the molar ratio of 4.8:2.3:1:0.15 and the second one of galacturonic acid: arabinose: galactose: rhamnose: xylose, in the molar ratio of 10.2:1.5:1:0.8:0.2. In turn, Zhang et al. separated S. divaricata polysaccharides into acid and neutral [63]. The acid polysaccharides had strong antioxidant activity, better than neutral. In vitro and in vivo studies demonstrated anticancer and immunomodulatory effects of $S$. divaricata polysaccharides. The results of Li et al. showed that these polysaccharides inhibited the growth of the implanted S180 murine sarcoma tumor and the inhibition was significantly higher when polysaccharides were used with IL-2 [64]. Moreover, K562 myelogenous leukemia cells treated with S. divaricata polysaccharides demonstrated decreased viability. The apoptosis was also confirmed and its percentage increased with increasing concentrations of polysaccharides [65]. Dong et al. obtained from the water extract of S. divaricata two polysaccharides, SDNP-1 and SDNP-2, having apparent molecular weight of $67.9 \times 10^{3}$ Da and $5.2 \times 10^{3} \mathrm{Da}$ [66]. They were composed of arabinose and galactose (molar ratio of about 1:1) and deduced to be AGII-type arabinogalactans having different backbone chains. SDNP-2, but not SDNP-1, could antagonize the immunosuppression by B16F10 melanoma cells on RAW264.7 macrophages.

In vitro anticancer effect of ethanolic extract from S. divaricata root was demonstrated by Kuo et al. [67]. At the concentration of $100 \mu \mathrm{g} / \mathrm{mL}$, this extract significantly suppressed the proliferation of different cancer cell lines: Raji human Burkitt's lymphoma, HeLa human cervical adenocarcinoma, Calu-1 human lung cancer, Wish (a HeLa derivative), K562 human chronic myelogenous leukemia and Vero cells, after $72 \mathrm{~h}$ of treatment. Moreover, according to these authors, the polyacetylene panaxynol, isolated from $S$. divaricata, blocked the proliferation of above cells. It did not significantly change the cell viabilities measured using the test based on the membrane integrity and thus it did not exhibit direct cytotoxicity. After the incubation with panaxynol, the cells were blocked at the G0/G1 phase of the cell cycle. In addition, the authors observed that it decreased mRNA content of cyclin E, which appears to be necessary for the G1/S transition. The authors suggested that panaxynol interfered with the regulatory events required for the entry of cancer cells into the $S$ phase of the cell cycle, which is related to the suppression of the cell proliferation. According to Chu et al., the traditional Chinese medicinal formula, containing, among others, the root of $S$. divaricata, by downregulating STAT3 (signal transducer and activator of transcription-3) signaling pathway playing the important function in the colorectal cancer progression, effectively suppressed the tumor growth and angiogenesis [68]. The induction of apoptosis by this formula might also be a main mechanism of the inhibition of tumor growth.

The results of the study of Tai and Cheung [18] indicate the potential applicability of $70 \%$ hydroethanolic extract from the root of S. divaricata as an element of combination therapy. This extract showed antiproliferative activities on HL60 human acute promyelocytic leukemia, MDA-MB-468 human mammary adenocarcinoma, K562 human chronic myelogenous leukemia and MCF7 human mammary adenocarcinoma cell lines. The most susceptible were HL60 cells and the least susceptible-MCF7. The combination of the extract with chemotherapeutic drugs, camptothecin or paclitaxel, demonstrated additive antiproliferative effects on the examined cells. However, the effects depended on the cell line and the doses of the drugs and S. divaricata extract. The results of the authors suggest that as a result of the co-administration of $S$. divaricata extract with lower doses of chemotherapeutic agents could be achieved a similar anti-proliferative effect to that when chemotherapeutics are administered alone, at higher doses, that can demonstrate toxic side-effects.

Treatment with juice from the root of $S$. divaricata, at the concentration of 10,1 and $0.1 \mathrm{mg} / \mathrm{mL}$, for $24 \mathrm{~h}$ and $50 \%$ hydroethanolic extract from this material, at the concentrations of 1, 0.1 and $0.01 \mathrm{mg} / \mathrm{mL}$, for $72 \mathrm{~h}$ resulted in a decrease of the viability of Caco- 2 cells. The juice compounds of molecular weight $>50 \mathrm{kDa}$ turned out to reduce the viability, after $24 \mathrm{~h}$ of treatment. The effect of juice and $50 \%$ hydroethanolic extract against the cell viability may be assigned to the presence of the proper concentrations of chromones, furanocoumarins, polyphenols, polysaccharides and other 
bioactive compounds typical for this herb and their additive or synergistic properties. The juice might have contained in the fraction $>50 \mathrm{kDa}$ the anticancer compounds which had not been efficiently obtained in the extracts, mainly polysaccharides. LDH activity in the medium, indicating the integrity of cell membranes, did not change after 24 -h incubation of the cells with juice and $50 \%$ hydroethanolic extract. Thus, they could have not exhibited direct cytotoxic activity. However, some concentrations of juice and this extract decreased LDH activity after $72 \mathrm{~h}$ of incubation. It may indicate the protective properties of contained chemical compounds in relation to the cell membranes. Moreover, juice and $50 \%$ hydroethanolic extract significantly increased the number of early apoptotic cells, after 24 of treatment. This extract also decreased the number of live cells, after $72 \mathrm{~h}$ of incubation. These prove that the bioactive compounds contained in juice and 50\% hydroethanolic extract from S. divaricata root limited, to some extent, the viability of Caco-2 cancer cells by inducing apoptosis. There is a high probability that juice and $50 \%$ hydroethanolic extract could have also reduced cell proliferation and affect the cell cycle, that requires further research.

\section{Materials and Methods}

\subsection{Plant Material and Preparation of Juice and Extracts}

Plant raw material (roots), about $1 \mathrm{~kg}$, was collected from three-year-old plants cultivated at the experimental field of the Department of Vegetable and Medicinal Plants, Warsaw University of Life Sciences (Warsaw, Poland). Seed material of $S$. divaricata used to establish experimental field plantation originated from wild growing population located in Mongolia. Underground organs were harvested in the late autumn, 2016. Voucher specimens were deposited at herbarium of the Department of Vegetable and Medicinal Plants, Warsaw University of Life Sciences.

One part (about $0.5 \mathrm{~kg}$ ) of the fresh raw material was used to obtain juice. The roots were washed and the juice was extracted in low temperature by single-auger low-speed juicer (Hurom HZS Alpha Plus, Hurom Co., Ltd., Gimhae-si, South Korea), then it was centrifuged two times (18516× $g, 10 \mathrm{~min}$ ), filtered (filter paper), separated for individual assays and stored $\left(-80^{\circ} \mathrm{C}\right)$.

The second part (about $0.5 \mathrm{~kg}$ ) of the fresh roots, directly after collection of plants, was washed and dried at $50{ }^{\circ} \mathrm{C}$, in the dark. Air-dry, powdered raw material $(5 \mathrm{~g})$ was extracted with $50 \mathrm{~mL}$ of the following solvents (a) water-to prepare water extract, (b) ethanol:water 50:50 (v/v)—to make 50\% hydroethanolic extract and (c) ethanol:water 75:25 (v/v)—to prepare 75\% hydroethanolic extract, using Büchi Extraction System B-811 (Büchi Labortechnik AG, Flawil, Switzerland). Soxhlet hot extraction with twenty five extraction cycles, for $5 \mathrm{~h} 10 \mathrm{~min}$ was used. The Soxhlet hot extracts were filtered and concentrated up to $5 \mathrm{~mL}$, using a rotary evaporator (Büchi R-200 Rotavapor System, Büchi Labortechnik AG, Flawil, Switzerland). The obtained extracts were frozen at $-80^{\circ} \mathrm{C}$, for 2 days and then subjected to lyophilization (Labconco FreeZone 2.5 freeze dryer, Labconco, Kansas City, MO, USA) for 2 days $\left(-50^{\circ} \mathrm{C}, 0.10 \mathrm{mbar}\right)$. Dry extracts were powdered in a porcelain mortar and stored in dark vials $\left(4^{\circ} \mathrm{C}\right)$.

\subsection{Analysis of Cimifugin $\beta$-D-glucopyranoside, Cimifugin, 4'-O-Glucopyranosyl-5-O-methylvisamminol and} Imperatorin by Ultra-High Performance Liquid Chromatography-Mass Spectrometry (UHPLC-MS)

The standards of above compounds (ChromaDex ${ }^{\circledR}$, Irvine, CA, USA) were dissolved in methanol, in $10 \mathrm{~mL}$ volumetric flasks, according to ChromaDex ${ }^{\circledR}$ Tech Tip 0003-Recovery \& Dilution Procedures [69] and used as standard stock solutions. A mixture of those standards was prepared by mixing $200 \mu \mathrm{l}$ of each standard stock solution with $800 \mu \mathrm{l}$ of water.

Juice and extracts were prepared, in triplicate, by the addition to their proper amount $(\sim 5280 \mathrm{mg}$ of juice (fresh matter) and $\sim 250 \mathrm{mg}$ of extracts) of proper amount of methanol (10 or $5 \mathrm{~mL}$, respectively). Then, $0.5 \mathrm{~mL}$ of methanolic solutions were mixed with $0.5 \mathrm{~mL}$ of water and filtered (polyvinylidene fluoride (PVDF) syringe filters with pore size $0.22 \mu \mathrm{m}$, EuroClone, Pero, Italy). 
An Agilent 1290 Infinity LC System (Agilent Technologies, Santa Clara, CA, USA) was used for high-resolution chromatographic separation of the analyzed compounds. The study was conducted using UHPLC coupled to ultra-high definition quadrupole time-of-flight (Q-TOF) mass spectrometry with the Agilent 1290 Infinity LC System with an Agilent 6540 Accurate-Mass Q-TOF LC/MS System (Agilent Technologies, Santa Clara, CA, USA). That system was used for identification of the peaks. The Q-TOF was operated in two modes: an initial MS-only mode, at extended dynamic range $2 \mathrm{~Hz}$ acquisition rate and an automatic MS/MS mode (data-dependent), with the masses of the investigated compounds. With the combined MS and MS/MS acquisition, the MS acquisition rate was 5 spectra/second and the mass range was set to 100-1000 m/z for both MS and MS/MS mode. Active exclusion mode was on and set to: exclude after 2 spectra, release after $0.05 \mathrm{~min}$. The charge state of the analyzed compounds was set to $1+, 2+$ and unknown. The fixed collision energies mode was chosen and set to 0,10, 20 and $40 \mathrm{eV}$. The mass spectrometer conditions for the Dual Agilent Jet Stream electrospray ionization (ESI) source were as follows: $350^{\circ} \mathrm{C}$ for the sheath gas temperature, $11 \mathrm{l} / \mathrm{min}$ for the sheath gas flow, $300{ }^{\circ} \mathrm{C}$ for the drying gas temperature, $8 \mathrm{l} / \mathrm{min}$ for the drying gas flow rate, $35 \mathrm{psi}$ for the nebulizer pressure, $3500 \mathrm{~V}$ for the capillary voltage in positive ion mode and $1000 \mathrm{~V}$ for the nozzle voltage. The fragmentor voltage was set to $135 \mathrm{~V}$ and all other mass spectrometer parameters remained at autotune conditions. Chromatographic separations were performed on a C18 column $\left(2.1 \times 150 \mathrm{~mm}\right.$, particle size $3 \mu \mathrm{m}$, LumiSep, Zgierz, Poland), at $40{ }^{\circ} \mathrm{C}$ and flow rate of $0.3 \mathrm{~mL} / \mathrm{min}$. Solvents consisted of: A-50 mL methanol, $950 \mathrm{~mL}$ water, $1 \mathrm{~mL}$ formic acid, B-800 mL methanol, $200 \mathrm{~mL}$ water, $1 \mathrm{~mL}$ formic acid. All components were of HPLC grade and were purchased from VWR International (Radnor, PA, USA). Analyses were performed according to the gradient settings: $100 \%$ A for $25 \mathrm{~min}, 100 \%$ B for $2 \mathrm{~min}, 100 \%$ B for $0.01 \mathrm{~min}, 100 \%$ A for $7.99 \mathrm{~min}$. Injection volume was $5 \mu \mathrm{L}$ throughout the chromatographic experiments and UV detection was at $254 \mathrm{~nm}$ for quantitative analysis. Amounts of four investigated compounds were calculated by comparing peak area for standard mixture and corresponding peak area for identified compound of interest in analyzed extracts. Each of three repeats $(n=3)$ of examined samples was injected twice and peaks from the second injection were integrated. The results were expressed in $\mu \mathrm{g}$ of the examined compound per $g$ of juice (fresh matter) or extract.

\subsection{Determination of Indicators of Redox State}

\subsubsection{Ferric-Reducing Antioxidant Power}

Ferric-reducing antioxidant power of juice and water, 50\% and 75\% hydroethanolic extracts from S. divaricata roots was assayed by the modified method of Oyaizu [70,71]. The method consists in reduction of $\mathrm{Fe}^{3+}$, present in stoichiometric excess in relation to antioxidants, due to donation of electrons by these compounds. The increase in absorbance is observed as the reduction capability increases. Juice and extracts were homogenized in deionized water and centrifuged $(1600 \times g, 10 \mathrm{~min})$. $2.5 \mathrm{~mL}$ of supernatants were mixed with $2.5 \mathrm{~mL}$ of $0.2 \mathrm{M}$ sodium phosphate buffer ( $\mathrm{pH} 6.6)$ and $2.5 \mathrm{~mL}$ of $1 \%$ potassium ferricyanide. The probes were incubated in a water bath $\left(50^{\circ} \mathrm{C}, 20 \mathrm{~min}\right)$ and $2.5 \mathrm{~mL}$ of $10 \%$ trichloroacetic acid (TCA) was added. The samples were centrifuged $(3000 \times g, 5 \mathrm{~min})$ and $0.4 \mathrm{~mL}$ of supernatants were mixed with $0.4 \mathrm{~mL}$ of deionized water and $160 \mu \mathrm{l}$ of $0.1 \%$ ferric chloride. The absorbance was recorded at $700 \mathrm{~nm}$, using microplate reader (Infinite M200, Tecan, Männedorf, Switzerland). The standard curve was constructed by applying different concentrations $(0-100 \mu \mathrm{M})$ of TROLOX (( \pm )-6-hydroxy-2,5,7,8-tetramethylchromane-2-carboxylic acid, a water-soluble vitamin $\mathrm{E}$ analog). The analysis was carried out in six repeats $(n=6)$.

4.3.2. 2.2'-Azino-bis(3-ethylbenzthiazoline-6-sulfonic Acid) Radical Cation (ABTS. ${ }^{+}$) Scavenging Activity

ABTS $^{+}{ }^{+}$a free radical which is relatively stable, decolorizes after reduction. To determine the scavenging activity of ABTS. ${ }^{+}$of juice and extracts from $S$. divaricata roots, they were prepared as in 
Section 4.3.1. and the procedure of Sun et al. with some modifications was applied [71,72]. The method consists in adding antioxidants to the ABTS.+ ${ }^{+}$solution and other ABTS. ${ }^{+}$is assessed spectrophotometrically. To prepare the ABTS reagent, $5 \mathrm{~mL}$ of $7 \mathrm{mM}$ ABTS was combined with $88 \mu \mathrm{l}$ of $140 \mathrm{mM} \mathrm{K}_{2} \mathrm{~S}_{2} \mathrm{O}_{8}$. In order to generate radicals, the reagent was placed in a dark site $(16 \mathrm{~h}$, room temperature (RT)). The absorbance was adjusted to $0.70 \pm 0.02$ (734 nm, microplate reader Infinite M200, Tecan, Männedorf, Switzerland) by dilution of the reagent with $99.8 \%$ ethanol. The scavenging activity of the radical cation was assayed by mixing of $0.9 \mathrm{~mL}$ of the ABTS reagent with $0.1 \mathrm{~mL}$ of supernatants derived from juice and extracts from S. divaricata roots. After the incubation ( $6 \mathrm{~min}, \mathrm{RT})$, the absorbance was read. The standard curve was constructed using TROLOX (as in Section 4.3.1.), $n=5$.

\subsubsection{2-Diphenyl-1-picrylhydrazyl Radical (DPPH •) Scavenging Activity}

To determine the scavenging activity of DPPH. of juice and extracts derived from the roots of S. divaricata (prepared as in Section 4.3.1.), the modified procedure of Li et al. was used [71,73]. In this method, the antioxidants provide a hydrogen or electron to the DPPH. unpaired electron and a decrease in absorbance is observed, proportional to rise in the DPPH non-radical form. $0.2 \mathrm{mM} \mathrm{DPPH}$ - solution in absolute methanol was combined with the supernatants derived from juice and extracts from S. divaricata roots $(2: 1, \mathrm{v} / \mathrm{v})$. After the incubation (30 $\mathrm{min}$, without light access), the samples were centrifuged $(15,000 \times g, 10 \mathrm{~min})$, then the supernatant absorbance was measured at $517 \mathrm{~nm}$ (microplate reader Infinite M200, Tecan, Männedorf, Switzerland). The standard curve was constructed as in Section 4.3.1, $n=6$.

\subsubsection{Glutathione}

Glutathione (GSH), an ubiquitous thiol tripeptide, constitutes almost $97 \%$ of non-protein thiol compounds in cells. By determination of non-protein -SH groups in deproteinized by TCA samples, GSH is determined quantitatively. The spectrophotometric method for the determination of non-protein -SH groups is based on the Ellman's method, in which 5,5'-dithiobis(2-nitrobenzoic acid) (DTNB, Ellman's reagent) is reduced by thiol compounds with the formation of colored 2-nitro-5-mercaptobenzoic acid, with a maximum of absorbance at $412 \mathrm{~nm}$ [74]. Juice and extracts from S. divaricata roots were homogenized in $0.1 \mathrm{M}$ phosphate buffer $\mathrm{pH} 7.4$ and centrifuged $(1600 \times g$, $10 \mathrm{~min}$ ). To deproteinize, to $1.5 \mathrm{~mL}$ of supernatants was added $78.96 \mu \mathrm{l}$ of $50 \%$ TCA and samples were centrifuged ( $3000 \mathrm{rpm}, 5 \mathrm{~min}$ ). Then, directly on a 96-well plate, $25 \mu \mathrm{l}$ of deproteinized supernatants were mixed with $200 \mu \mathrm{l}$ of $0.2 \mathrm{M}$ phosphate buffer $\mathrm{pH} 8.0$ and with $25 \mu \mathrm{l}$ of $6 \times 10^{-3} \mathrm{M}$ DTNB. The absorbance was recorded using microplate reader (Infinite M200, Tecan, Männedorf, Switzerland). The standard curve was constructed by applying different concentrations $(0-75 \mathrm{nmol} / \mathrm{mL})$ of GSH standard in $2.5 \%$ TCA, $n=6$.

\subsection{Determination of Total Carbohydrates, Protein and Fat}

Content of total carbohydrates in juice and extracts from S. divaricata roots was measured by the method using phenol and sulfuric acid [75]. Glucose was used to construct a standard curve and the absorbance was recorded at $490 \mathrm{~nm}, n=3$.

Concentration of total protein in juice and extracts was determined using the Bradford method and the standard was bovine serum albumin (BSA) [76], $n=6$.

Content of total lipids in juice and 50\% hydroethanolic extract was measured using the Folch method [77], $n=2$.

\subsection{Determination of Polyphenols}

The method for determining the total amount of polyphenols in a sample, the Folin-Ciocalteu method, involves the measurement of the absorbance of the complex resulting from the reduction of salts of hetero polyacids, phosphomolybdic and phosphotungstic, so-called Folin-Ciocalteu reagent [78]. During the reaction Mo (VI) ions are reduced to Mo $(\mathrm{V})$, which results in a blue color originating 
from $\left[\mathrm{PMoW}_{11} \mathrm{O}_{40}\right]^{4-}$. To determine the concentration of polyphenols, juice and extracts derived from the roots of $S$. divaricata were prepared as in Section 4.3.1. Then, $0.5 \mathrm{~mL}$ of supernatants were mixed with $2.5 \mathrm{~mL}$ of Folin-Ciocalteu reagent (1:10 diluted with deionized water). After 2 min of incubation, the samples were combined with $2 \mathrm{~mL}$ of $7.5 \% \mathrm{Na}_{2} \mathrm{CO}_{3}$. After incubation in a water bath $\left(50^{\circ} \mathrm{C}, 10 \mathrm{~min}\right.$ ), the absorbance was measured at $760 \mathrm{~nm}$, in a cuvette spectrophotometer (Spectronic 20D, Milton Roy, Rochester, NY, USA). The standard curve was constructed by applying different concentrations $(0-100 \mu \mathrm{g} / \mathrm{mL})$ of quercetin, $n=3$.

\subsection{Preparation of Juice and Extracts and Their Fractions for Cell Culture Tests}

Before each cell culture test, water, $50 \%$ and $75 \%$ hydroethanolic extracts from $S$. divaricata roots were dissolved in deionized water, at the concentration of $10 \mathrm{mg} / \mathrm{mL}$ (experiment described in Section 4.8.) or $15.9 \mathrm{mg} / \mathrm{mL}$ (other tests). The juice was diluted to obtain the same concentrations as the extracts, analogically (concentrations of juice concern its dry matter (dry matter of undiluted juice $=159 \mathrm{mg} / \mathrm{mL})$ ). Then, juice and extracts were subjected to centrifugation $(1600 \times g, 10 \mathrm{~min})$ and the supernatants were collected.

Considering the results of the experiment described in Section 4.8., part of juice and $50 \%$ hydroethanolic extract $(159 \mathrm{mg} / \mathrm{mL})$ was filtered using PVDF syringe filters $(0.22 \mu \mathrm{m}$, EuroClone, Pero, Italy). Then, juice and $50 \%$ extract were fractionated in terms of molecular weight, by applying ultra centrifugal filter devices containing the membrane made of regenerated cellulose (Merck Millipore, Burlington, MA, USA), that included 3, 10 or $50 \mathrm{kDa}$ cutoffs, in accordance with the manufacturer's recommendations regarding centrifugation time and g-force. Four fractions were acquired: $>50 \mathrm{kDa}$ ( $>50 \mathrm{~K}), 10-50 \mathrm{kDa}(10-50 \mathrm{~K}), 3-10 \mathrm{kDa}(3-10 \mathrm{~K})$ and $<3 \mathrm{kDa}(<3 \mathrm{~K})$.

Before cell culture tests, juice, extracts and fractions were sterilized (PVDF syringe filters, $0.22 \mu \mathrm{m}$, EuroClone, Pero, Italy), under the biological safety cabinet (TopSafe ${ }^{\mathrm{TM}} 1.2$, class II, BIOAIR, Pavia, Italy). Their appropriate decimal dilutions were prepared for individual tests, using sterile deionized water.

\subsection{Caco-2 Cell Culture}

Human epithelial colorectal adenocarcinoma (Caco-2) cell line (ECCC, 55 passage, Sigma-Aldrich, St. Louis, MO, USA) was cultured in polystyrene plates intended for adherent cell culture (for viability and membrane integrity tests-in 96-well plates, at a density of $1 \times 10^{4}$ cells/100 $\mu \mathrm{l}$ and for types of cell death tests-in 6-well plates, at a density of $0.75 \times 10^{5}$ cells/1.5 mL) in Minimum Essential Medium (MEM) with $2 \mathrm{mM}$ L-glutamine (Thermo Fisher Scientific, Waltham, MA, USA), 10\% fetal bovine serum (FBS, Thermo Fisher Scientific, Waltham, MA, USA), 1\% non-essential amino acids (NEAA, Thermo Fisher Scientific, Waltham, MA, USA) and 1\% antibiotic-antimycotic (Thermo Fisher Scientific, Waltham, MA, USA) [71]. The cells were placed in a $\mathrm{CO}_{2}$ incubator (INCO 108 med, Memmert $\mathrm{GmbH}+\mathrm{Co}$. KG, Schwabach, Germany) at $37{ }^{\circ} \mathrm{C}\left(5 \% \mathrm{CO}_{2}, 95 \%\right.$ relative humidity). After incubation for $24 \mathrm{~h}$ and reaching about $70 \%$ confluence, they were starved overnight in MEM (Thermo Fisher Scientific, Waltham, MA, USA) with 1\% FBS (Thermo Fisher Scientific, Waltham, MA, USA) and 1\% antibiotic-antimycotic (Thermo Fisher Scientific, Waltham, MA, USA) [71].

\subsection{Effect of Juice and Extracts on Cell Viability}

Ninety $\mu \mathrm{L}$ of fresh medium (MEM with $1 \%$ FBS and $1 \%$ antibiotic-antimycotic, see Section 4.7.) and $10 \mu \mathrm{L}$ of juice, water, $50 \%$ hydroethanolic extract and $75 \%$ hydroethanolic extract from S. divaricata roots, at the concentrations of $10,1,0.1$ and $0.01 \mathrm{mg} / \mathrm{mL}$ were added to the cells. The same volumes of sterile deionized water were introduced into the control cells. Various additional controls were included. After incubation $\left(\mathrm{CO}_{2}\right.$ incubator INCO 108 med, Memmert GmbH + Co. KG, Schwabach, Germany; $37^{\circ} \mathrm{C}, 5 \% \mathrm{CO}_{2}, 95 \%$ relative humidity) for $24 \mathrm{~h}$ and $72 \mathrm{~h}$, the MTT (methylthia-zolyldiphenyl-tetrazolium bromide) test was carried out by the modified procedure of Tada et al. [79]. A yellow solution of MTT is converted by mitochondrial dehydrogenases of live cells to dark blue, water-insoluble MTT formazan. In brief, $15 \mu \mathrm{l}$ of MTT reagent (Sigma-Aldrich, St. Louis, MO, USA) in PBS (phosphate-buffered saline) 
at $5 \mathrm{mg} / \mathrm{mL}$ was introduced into the cells and the plates were incubated $\left(37^{\circ} \mathrm{C}, 4 \mathrm{~h}\right)$. Then, $100 \mu \mathrm{l}$ of lysis buffer $(10 \%$ sodium dodecyl sulfate in $0.01 \mathrm{M} \mathrm{HCl})$ was introduced, plates were incubated $\left(37^{\circ} \mathrm{C}\right.$, overnight) and the absorbance was recorded at $570 \mathrm{~nm}$ using microplate reader (Infinite M200, Tecan, Männedorf, Switzerland), $n=5$.

\subsection{Effect of Fractions of Juice and 50\% Hydroethanolic Extract on Cell Viability}

Ninety $\mu \mathrm{L}$ of fresh medium and $10 \mu \mathrm{L}$ of four fractions: $>50 \mathrm{kDa}(>50 \mathrm{~K}), 10-50 \mathrm{kDa}(10-50 \mathrm{~K})$, 3-10 kDa $(3-10 \mathrm{~K})$ and $<3 \mathrm{kDa}(<3 \mathrm{~K})$ of juice from $S$. divaricata roots, at the concentrations of 15.9, $15.9 \times 10^{-1}, 15.9 \times 10^{-2}$ and $15.9 \times 10^{-3} \mathrm{mg} / \mathrm{mL}$ or the same concentrations of the same fractions of $50 \%$ hydroethanolic extract (the concentration of the extract before fractionation corresponded to the dry matter of the juice) were added to the cells. The same controls as in Section 4.8. were included. After $24 \mathrm{~h}$ of incubation of the cells with juice and extract fractions, the MTT test was performed, as in Section 4.8. $n=5$.

\subsection{Effect of Juice and 50\% Hydroethanolic Extract on Membrane Integrity}

Damage to the cell membrane releases a cytosolic enzyme, lactate dehydrogenase (LDH) into the medium. It can be quantified using a coupled enzymatic reaction. LDH is a catalyst of the conversion of lactate to pyruvate via $\mathrm{NAD}^{+}$reduction to NADH. Then, diaphorase uses NADH to reduce INT (terazolium salt) to a red formazan which content is recorded at $490 \mathrm{~nm}$. The LDH test was performed following the recommendations of the manufacturer of the commercial kit used (Thermo Fisher Scientific, Waltham, MA, USA). To the cells were added $100 \mu \mathrm{L}$ of fresh medium and $10 \mu \mathrm{L}$ of juice or $50 \%$ hydroethanolic extract from S. divaricata roots, at the concentrations of 15.9, $15.9 \times 10^{-1}, 15.9 \times 10^{-2}, 15.9 \times 10^{-3}, 15.9 \times 10^{-4}$ and $15.9 \times 10^{-5} \mathrm{mg} / \mathrm{mL}$. The same volumes of sterile deionized water were introduced into the control cells. Different additional controls were included. After incubation $\left(\mathrm{CO}_{2}\right.$ incubator INCO 108 med, Memmert GmbH + Co. KG, Schwabach, Germany; $37^{\circ} \mathrm{C}, 5 \% \mathrm{CO}_{2}, 95 \%$ relative humidity) for $24 \mathrm{~h}$ and $72 \mathrm{~h}, \mathrm{LDH}$ activity in cell culture medium was determined and expressed as \% of maximum LDH activity (in medium after lysis of the cells), $n=6$.

\subsection{Effect of Juice and 50\% Hydroethanolic Extract on Types of Cell Death}

To the cells were added $1.5 \mathrm{~mL}$ of fresh medium and $150 \mu \mathrm{L}$ of juice or $50 \%$ hydroethanolic extract from S. divaricata roots, at the concentrations of $15.9 \times 10^{-1}$ and $15.9 \times 10^{-2} \mathrm{mg} / \mathrm{mL}$. The same volumes of sterile deionized water were introduced into the control cells. After incubation of the cells $\left(\mathrm{CO}_{2}\right.$ incubator INCO 108 med, Memmert GmbH + Co. KG, Schwabach, Germany; $37^{\circ} \mathrm{C}, 5 \% \mathrm{CO}_{2}$, $95 \%$ relative humidity) for $24 \mathrm{~h}\left(15.9 \times 10^{-1} \mathrm{mg} / \mathrm{mL}\right)$ and for $72 \mathrm{~h}\left(15.9 \times 10^{-2} \mathrm{mg} / \mathrm{mL}\right)$, the types of cell death were evaluated according to the instructions of the manufacturer of the commercial kit for flow cytometry with Alexa Fluor ${ }^{\circledR} 488$ Annexin V and propidium iodide (PI) (Thermo Fisher Scientific, Waltham, MA, USA). PI is a fluorescent dye which stains dead cells binding to the nucleic acids and Annexin V conjugated to fluorophore Alexa Fluor ${ }^{\circledR} 488$ binds to phosphatidyl serine exposed on the outer surface of the cell membrane of the apoptotic cells. Live cells are unstained, Annexin V-positive cells are considered as early apoptotic, PI/Annexin V-positive cells as late apoptotic and PI-positive cells as necrotic. The cells were harvested by trypsinization and washed twice in cold PBS. After centrifugation and removal of the supernatant, the cell pellets were resuspended in $100 \mu \mathrm{l}$ of Annexin-binding buffer. Then, $5 \mu \mathrm{l}$ of Alexa Fluor ${ }^{\circledR} 488$ Annexin V and $1 \mu \mathrm{l}$ of PI working solution were added to each cell suspension. The cells were incubated for $15 \mathrm{~min}$ (RT). Then, $400 \mu \mathrm{l}$ of Annexin-binding buffer was added, the samples were gently mixed and kept on ice until they were introduced into the flow cytometer. The stained cells were analyzed by BDFACSCalibur ${ }^{\mathrm{TM}}$ flow cytometer (Becton Dickinson, Franklin Lakes, NJ, USA), intensity of fluorescence emission was measured using FL1 channel for Alexa Fluor ${ }^{\circledR} 488$ at $530 \mathrm{~nm}$ and FL2 for PI at $575 \mathrm{~nm}$, using excitation at $488 \mathrm{~nm}$. Ten thousand (24-h test) or forty thousand events (72-h test) were recorded per sample. Plots were generated using Flowing Software 2.5.1 (Perttu Terho, Turku, Finland), $n=6$. 
The cells were imaged by an inverted light microscope DMi8 equipped with a MC190 HD camera, using the LAS V4.10 software (Leica, Wetzlar, Germany).

\subsection{Statistical Analysis}

The results are expressed as the mean \pm the standard error of the mean (SEM). The results of the part concerning the chemical composition were subjected to a one-way analysis of variance (ANOVA) and the means were compared by the Tukey's post-hoc test. Statgraphics Centurion software (StatPoint Technologies, Inc., Warrenton, VA, USA) was used. The results of tests on cells were subjected to ANOVA, the mean values for juice and extract treated groups were compared to deionized water treated group by the Dunnett's post-hoc test. Prism 5 software (GraphPad Software Inc., San Diego, CA, USA) was applied. The difference at $p<0.05$ between the means was considered statistically significant.

\section{Conclusions}

The examined chromones (cimifugin $\beta$-D-glucopyranoside, cimifugin and 4'-O-glucopyranosyl-5-O-methylvisamminol) and furanocoumarin imperatorin were contained in juice from S. divaricata root in the largest concentrations. Juice and extracts, due to the presence of antioxidants, that were characterized by the electron or hydrogen donor properties to neutralize free radicals, have the ability to reduce the oxidative stress in the organism and may be a valuable chemopreventive diet components decreasing the colon cancer risk. The content of GSH, responsible for maintenance of the intracellular redox balance, as hydrophilic compound, was the highest in water extract. The major contributor to the antioxidative activity of juice and extracts were the most probably polyphenols. The concentration of carbohydrates was the highest in juice and $75 \%$ hydroethanolic extract. The decrease of the viability of the colon cancer cells Caco-2, after the application of juice and $50 \%$ hydroethanolic extract from the root of $S$. divaricata was affirmed in the present work for the first time. This effect could be related to presence of chromones, furanocoumarins, polyphenols, polysaccharides and other bioactive compounds typical for S. divaricata, at proper concentrations, and their additive or synergistic properties. The observed reduction of the cell viability after the use of the fraction of juice with the molecules $>50 \mathrm{kDa}$ may be assigned to the presence of anticancer compounds which were not efficiently obtained in the extracts, mainly polysaccharides. Some chemical compounds of juice and 50\% hydroethanolic extract could have exhibited the protective properties in relation to the cell membranes. The viability of Caco- 2 cancer cells after the application of juice and $50 \%$ hydroethanolic extract was decreased to some extent by inducing apoptosis. The knowledge of further exact mechanisms of anticancer activity of the examined natural products from S. divaricata will allow to consider the use of juice and $50 \%$ hydroethanolic extract as part of combination therapy of colon cancer. The conventional treatment in combination with these natural products may affect more signaling pathways decreasing the development of resistance to chemotherapeutics, increase the sensitivity to anticancer drugs and minimize adverse effects of therapy.

Author Contributions: Conceptualization, M.M., K.B.B., I.K., T.N. and Z.W.; methodology, M.M., K.B.B., I.K., M.G., Z.W.; software, M.M., J.S.; validation, M.M. and K.B.B.; formal analysis, M.M.; investigation, M.M., K.B.B., J.S., S.O., Z.W.; resources, M.M., K.B.B., I.K., T.N., Z.W.; data curation, M.M.; writing-original draft preparation, M.M., K.B.B., Z.W.; writing - review and editing, I.K.; visualization, M.M.; supervision, M.M.; project administration, M.M.; funding acquisition, M.M." This work is part of a habilitation thesis by M.M.

Funding: The research was funded by the National Science Centre, Poland, "Miniatura" Project, No. 2017/01/X/NZ9/00195. We received funds for covering the costs to publish in open access.

Conflicts of Interest: The authors declare no conflict of interest.

\section{References}

1. Bray, F.; Ferlay, J.; Soerjomataram, I.; Siegel, R.L.; Torre, L.A.; Jemal, A. Global cancer statistics 2018: GLOBOCAN estimates of incidence and mortality worldwide for 36 cancers in 185 countries. CA Cancer J. Clin. 2018, 68, 394-424. [CrossRef] [PubMed] 
2. Rejhova, A.; Opattova, A.; Čumová, A.; Slíva, D.; Vodička, P. Natural compounds and combination therapy in colorectal cancer treatment. Eur. J. Med. Chem. 2018, 144, 582-594. [CrossRef] [PubMed]

3. Arnold, M.; Sierra, M.S.; Laversanne, M.; Soerjomataram, I.; Jemal, A.; Bray, F. Global patterns and trends in colorectal cancer incidence and mortality. Gut 2017, 66, 683-691. [CrossRef] [PubMed]

4. Redondo-Blanco, S.; Fernández, J.; Gutiérrez-del-Río, I.; Villar, C.J.; Lombó, F. New insights toward colorectal cancer chemotherapy using natural bioactive compounds. Front. Pharm. 2017, 8, 109. [CrossRef] [PubMed]

5. van der Stok, E.P.; Spaander, M.C.; Grünhagen, D.J.; Verhoef, C.; Kuipers, E.J. Surveillance after curative treatment for colorectal cancer. Nat. Rev. Clin. Oncol. 2017, 14, 297. [CrossRef] [PubMed]

6. Nobili, S.; Lippi, D.; Witort, E.; Donnini, M.; Bausi, L.; Mini, E.; Capaccioli, S. Natural compounds for cancer treatment and prevention. Pharm. Res 2009, 59, 365-378. [CrossRef] [PubMed]

7. Housman, G.; Byler, S.; Heerboth, S.; Lapinska, K.; Longacre, M.; Snyder, N.; Sarkar, S. Drug resistance in cancer: an overview. Cancers 2014, 6, 1769-1792. [CrossRef]

8. Singh, C.K.; George, J.; Ahmad, N. Resveratrol-based combinatorial strategies for cancer management. Ann N. Y. Acad Sci 2013, 1290, 113-121. [CrossRef]

9. Pan, M.H.; Lai, C.S.; Wu, J.C.; Ho, C.T. Molecular mechanisms for chemoprevention of colorectal cancer by natural dietary compounds. Mol Nutr Food Res 2011, 55, 32-45. [CrossRef]

10. Li, X.; Wei, W. Chinese Materia Medica-Combinations and applications; Donica Publishing Ltd.: St Albans, UK, 2002.

11. Urgamal, M. Description of species Saposhnikovia divaricata Schischkin (Umbelliferae Juss.) in Mongolia. Proc. Inst. Bot. Mong. Acad. Sci. 2006, 16, 51-55.

12. Khan, I.A.; Abourashed, E.A. Leung's Encyclopedia of Common Natural Ingredients: Used in Food, Drugs and Cosmetics, 3rd ed.; Wiley: Hoboken, NJ, USA, 2010; pp. 281-282.

13. Scherübl, R.; Manns, D.; Heilmann, J.; Franz, G. Comparison of HPLC Versus HPTLC-Densitometry for the Quantification of Chromone Glucosides in Saposhnikoviae divaricatae Radix. Chromatographia 2013, 76, 1537-1543. [CrossRef]

14. Shiozaki, Y. The Japanese Pharmacopoeia, 17th ed.; The Ministry of Health, Labour and Welfare: Tokyo, Japan, 2016; pp. 1971-1972.

15. Kreiner, J.; Pang, E.; Lenon, G.B.; Yang, A.W.H. Saposhnikoviae divaricata: a phytochemical, pharmacological, and pharmacokinetic review. Chin J Nat Med 2017, 15, 255-264. [CrossRef]

16. Kong, X.; Liu, C.; Zhang, C.; Zhao, J.; Wang, J.; Wan, H.; Zhu, H.; Zhang, P.; Chen, W.; Xiao, Y.; et al. The suppressive effects of Saposhnikovia divaricata (Fangfeng) chromone extract on rheumatoid arthritis via inhibition of nuclear factor- $\mathrm{kB}$ and mitogen activated proteinkinases activation on collagen-induced arthritis model. J. Ethnopharmacol 2013, 148, 842-850. [CrossRef]

17. Chun, J.M.; Kim, H.S.; Lee, A.Y.; Kim, S.H.; Kim, H.K. Anti-Inflammatory and Antiosteoarthritis Effects of Saposhnikovia divaricata Ethanol Extract: In Vitro and In Vivo Studies. Evid. Based Complement Altern. Med. 2016, 2016, 8. [CrossRef]

18. Tai, J.; Cheung, S. Anti-proliferative and antioxidant activities of Saposhnikovia divaricata. Oncol. Rep. 2007, 18, $227-234$. [CrossRef]

19. Chinese Pharmacopoeia Commission. Pharmacopoeia of the People's Republic of China, English ed.; People's Medical Publishing House: Beijing, China, 2010; Volume 1.

20. Okuyama, E.; Hasegawa, T.; Matsushita, T.; Fujimoto, H.; Ishibashi, M.; Yamazaki, M. Analgesic Components of Saposhnikovia Root (Saposhnikovia divaricata). Chem. Pharm. Bull. 2001, 49, 154-160. [CrossRef]

21. Kim, M.K.; Yang, D.H.; Jung, M.; Jung, E.H.; Eom, H.Y.; Suh, J.H.; Min, J.W.; Kim, U.; Min, H.; Kim, J.; et al. Simultaneous determination of chromones and coumarins in Radix Saposhnikoviae by high performance liquid chromatography with diode array and tandem mass detectors. J Chromatogr A 2011, 1218, 6319-6330. [CrossRef]

22. Yokosuka, A.; Tatsuno, S.; Komine, T.; Mimaki, Y. Chemical Constituents of the Roots and Rhizomes of Saposhnikovia divaricata and their Cytotoxic Activity. Nat. Prod. Commun. 2017, 12, 255-258. [CrossRef]

23. Xue, B.Y.; Li, W.; Li, L.; Xiao, Y.Q. A pharmacodynamic research on chromone glucosides of fangfeng. China J. Chin. Mater. Med. 2000, 25, 297-299.

24. Chen, N.; Wu, Q.; Chi, G.; Soromou, L.W.; Hou, J.; Deng, Y.; Feng, H. Prime-O-glucosylcimifugin attenuates lipopolysaccharide-induced acute lung injury in mice. Int. Immunopharmacol. 2013, 16, 139-147. [CrossRef] 
25. Zhao, B.; Yang, X.B.; Yang, X.W.; Liu, J.X. Biotransformation of prim-O-glucosylcimifugin by human intestinal flora and its inhibition on NO production and DPPH free radical. J. Asian Nat. Prod. Res. 2012, 14, 886-896. [CrossRef]

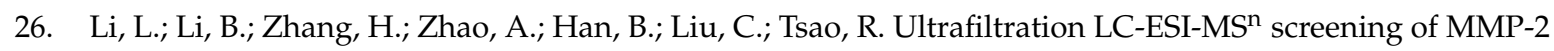
inhibitors from selected Chinese medicinal herbs Smilax glabra Roxb., Smilax china L. and Saposhnikovia divaricata (Turcz.) Schischk as potential functional food ingredients. J. Funct. Foods 2015, 15, 389-395. [CrossRef]

27. Kozioł, E.; Skalicka-Woźniak, K. Imperatorin-pharmacological meaning and analytical clues: profound investigation. Phytochem. Rev. 2016, 15, 627-649. [CrossRef]

28. Zhang, L.; Liu, X.; Lu, X.; Huang, C. Prim-O-glucosylcimifugin induces cell cycle arrest and apoptosis in acute lymphoblastic leukemia cells. Anticancer Drugs 2017, 28, 943-951. [CrossRef]

29. Huyen, C.; Luyen, B.; Khan, G.; Oanh, H.; Hung, T.; Li, H.J.; Li, P. Chemical Constituents from Cimicifuga dahurica and Their Anti-Proliferative Effects on MCF-7 Breast Cancer Cells. Molecules 2018, 23, 1083. [CrossRef]

30. Soler, M.C.; Molina, J.L.; Díaz, H.A.; Pinto, V.C.; Barrios, Y.L.; He, K.; Roller, M.; Weinstein-Oppenheimer, C.R. Effect of the standardized Cimicifuga foetida extract on Hsp 27 expression in the MCF-7 cell line. Biol. Res. 2011, 44, 243-249. [CrossRef]

31. Ma, S.Y.; Shi, L.G.; Gu, Z.B.; Wu, Y.L.; Wei, L.B.; Wei, Q.Q.; Gao, X.L.; Liao, N. Two New Chromone Glycosides from the Roots of Saposhnikovia divaricata. Chem. Biodivers. 2018, 15, e1800253. [CrossRef]

32. Kim, Y.K.; Kim, Y.S.; Ryu, S.Y. Antiproliferative Effect of Furanocoumarins from the Root of Angelica dahurica on Cultured Human Tumor Cell Lines. Phytother Res 2007, 21, 288-290. [CrossRef]

33. Um, Y.R.; Kong, C.S.; Im Lee, J.; Kim, Y.A.; Nam, T.J.; Seo, Y. Evaluation of chemical constituents from Glehnia littoralis for antiproliferative activity against HT-29 human colon cancer cells. Process Biochem. 2010, 45, 114-119. [CrossRef]

34. Rahman, A.; Alam Siddiqui, S.; Jakhar, R.; Chul Kang, S. Growth Inhibition of Various Human Cancer Cell Lines by Imperatorin and Limonin from Poncirus Trifoliata Rafin. Seeds. Anticancer Agents Med. Chem. 2015, 15, 236-241. [CrossRef]

35. Zheng, Y.M.; Lu, A.X.; Shen, J.Z.; Kwok, A.H.Y.; Ho, W.S. Imperatorin exhibits anticancer activities in human colon cancer cells via the caspase cascade. Oncol. Rep. 2016, 35, 1995-2002. [CrossRef]

36. Mi, C.; Ma, J.; Wang, K.S.; Zuo, H.X.; Wang, Z.; Li, M.Y.; Piao, L.X.; Xu, G.H.; Li, X.; Quan, Z.S.; et al. Imperatorin suppresses proliferation and angiogenesis of human colon cancer cell by targeting HIF- $1 \alpha$ via the mTOR/p70S6K/4E-BP1 and MAPK pathways. J. Ethnopharmacol. 2017, 203, 27-38. [CrossRef]

37. Zhao, B.; Yang, X.B.; Yang, X.W.; Wu, Q.; Wang, Y.; Zhang, L.X.; Xu, W. Intestinal permeability of the constituents from the roots of Saposhnikovia divaricata in the human Caco-2 cell monolayer model. Planta Med. 2011, 77, 1531-1535. [CrossRef]

38. Li, Y.; Zhao, L.; Zhang, H.; Jia, J.; Lv, L.; Zhou, G.; Chai, Y.; Zhang, G. Comparative pharmacokinetics of prim-O-glucosylcimifugin and cimifugin by liquid chromatography-mass spectrometry after oral administration of Radix Saposhnikoviae extract, cimifugin monomer solution and prim-O-glucosylcimifugin monomer solution to rats. Biomed. Chromatogr. 2012, 26, 1234-1240. [CrossRef]

39. Gao, Y.; Luan, L.B. In situ rat intestinal absorption of two active components in Radix Angelicae Dahuricae extracts. Chin. J. New Drugs 2007, 14.

40. Cai, F.; Dupertuis, Y.M.; Pichard, C. Role of polyunsaturated fatty acids and lipid peroxidation on colorectal cancer risk and treatments. Curr. Opin. Clin. Nutr. Metab. Care 2012, 15, 99-106. [CrossRef]

41. Ak, T.; Gülçin, İ. Antioxidant and radical scavenging properties of curcumin. Chem.-Biol. Interact. 2008, 174, $27-37$. [CrossRef]

42. Traverso, N.; Ricciarelli, R.; Nitti, M.; Marengo, B.; Furfaro, A.L.; Pronzato, M.A.; Marinari, U.M.; Domenicotti, C. Role of glutathione in cancer progression and chemoresistance. Oxid. Med. Cell Longev. 2013, 2013, 10. [CrossRef]

43. Balendiran, G.K.; Dabur, R.; Fraser, D. The role of glutathione in cancer. Cell Biochem. Funct. 2004, 22, 343-352. [CrossRef]

44. Zhang, L.; Ravipati, A.S.; Koyyalamudi, S.R.; Jeong, S.C.; Reddy, N.; Smith, P.T.; Bartlett, J.; Shanmugam, K.; Münch, G.; Wu, M.J. Antioxidant and anti-inflammatory activities of selected medicinal plants containing phenolic and flavonoid compounds. J. Agric. Food Chem. 2011, 59, 12361-12367. [CrossRef] 
45. Song, F.L.; Gan, R.Y.; Zhang, Y.; Xiao, Q.; Kuang, L.; Li, H.B. Total Phenolic Contents and Antioxidant Capacities of Selected Chinese Medicinal Plants. Int. J. Mol. Sci. 2010, 11, 2362-2372. [CrossRef] [PubMed]

46. Park, J.H.; Kang, S.N.; Chu, G.M.; Jin, S.K. Growth performance, blood cell profiles, and meat quality properties of broilers fed with Saposhnikovia divaricata, Lonicera japonica, and Chelidonium majus extracts. Livest. Sci. 2014, 165, 87-94. [CrossRef]

47. Sadeghi Ekbatan, S.; Li, X.Q.; Ghorbani, M.; Azadi, B.; Kubow, S. Chlorogenic acid and its microbial metabolites exert anti-proliferative effects, S-phase cell-cycle arrest and apoptosis in human colon cancer caco-2 cells. Int. J. Mol. Sci. 2018, 19, 723. [CrossRef] [PubMed]

48. Hou, N.; Liu, N.; Han, J.; Yan, Y.; Li, J. Chlorogenic acid induces reactive oxygen species generation and inhibits the viability of human colon cancer cells. Anticancer Drugs 2017, 28, 59-65. [CrossRef] [PubMed]

49. Matsunaga, K.; Katayama, M.; Sakata, K.; Kuno, T.; Yoshida, K.; Yamada, Y.; Hirose, Y.; Yoshimi, N.; Mori, H. Inhibitory effects of chlorogenic acid on azoxymethane-induced colon carcinogenesis in male F344 rats. Asian Pac. J. Cancer Prev. 2002, 3, 163-166. [PubMed]

50. Kang, N.J.; Lee, K.W.; Kim, B.H.; Bode, A.M.; Lee, H.J.; Heo, Y.S.; Boardman, L.; Limburg, P.; Lee, H.J.; Dong, Z. Coffee phenolic phytochemicals suppress colon cancer metastasis by targeting MEK and TOPK. Carcinogenesis 2011, 32, 921-928. [CrossRef] [PubMed]

51. Giftson, J.S.; Jayanthi, S.; Nalini, N. Chemopreventive efficacy of gallic acid, an antioxidant and anticarcinogenic polyphenol, against 1,2-dimethyl hydrazine induced rat colon carcinogenesis. Invest New Drug 2010, 28, 251-259. [CrossRef] [PubMed]

52. Subramanian, A.P.; Jaganathan, S.K.; Mandal, M.; Supriyanto, E.; Muhamad, I.I. Gallic acid induced apoptotic events in HCT-15 colon cancer cells. World J. Gastroenterol. 2016, 22, 3952-3961. [CrossRef] [PubMed]

53. Forester, S.C.; Choy, Y.Y.; Waterhouse, A.L.; Oteiza, P.I. The Anthocyanin Metabolites Gallic Acid, 3-O-Methylgallic Acid, and 2, 4, 6-Trihydroxybenzaldehyde Decrease Human Colon Cancer Cell Viability by Regulating Pro-Oncogenic Signals. Mol. Carcinog. 2014, 53, 432-439. [CrossRef] [PubMed]

54. Jaganathan, S.K. Growth inhibition by caffeic acid, one of the phenolic constituents of honey, in HCT 15 colon cancer cells. Sci. World J. 2012, 2012, 8. [CrossRef] [PubMed]

55. Fong, Y.; Tang, C.C.; Hu, H.T.; Fang, H.Y.; Chen, B.H.; Wu, C.Y.; Yuan, S.S.; Wang, H.M.D.; Chen, Y.C.; Teng, Y.N.; et al. Inhibitory effect of trans-ferulic acid on proliferation and migration of human lung cancer cells accompanied with increased endogenous reactive oxygen species and $\beta$-catenin instability. Chin. Med. 2016, 11, 45. [CrossRef] [PubMed]

56. Dinicola, S.; Cucina, A.; Pasqualato, A.; D'Anselmi, F.; Proietti, S.; Lisi, E.; Pasqua, G.; Antonacci, D.; Bizzarri, M. Antiproliferative and Apoptotic Effects Triggered by Grape Seed Extract (GSE) versus Epigallocatechin and Procyanidins on Colon Cancer Cell Lines. Int. J. Mol. Sci. 2012, 13, 651-664. [CrossRef] [PubMed]

57. Uesato, S.; Kitagawa, Y.; Kamishimoto, M.; Kumagai, A.; Hori, H.; Nagasawa, H. Inhibition of green tea catechins against the growth of cancerous human colon and hepatic epithelial cells. Cancer. Lett. 2001, 170, 41-44. [CrossRef]

58. Yang, G.Y.; Liao, J.; Kim, K.; Yurkow, E.J.; Yang, C.S. Inhibition of growth and induction of apoptosis in human cancer cell lines by tea polyphenols. Carcinogenesis 1998, 19, 611-616. [CrossRef] [PubMed]

59. Ibrahim, A.; Sobeh, M.; Ismail, A.; Alaa, A.; Sheashaa, H.; Sobh, M.; Badria, F. Free-B-Ring flavonoids as potential lead compounds for colon cancer therapy. Mol. Clin. Oncol. 2014, 2, 581-585. [CrossRef] [PubMed]

60. Gao, Y.Y.; Jiang, Y.; Chen, G.C.; Li, S.S.; Yang, F.; Ma, Q. A Sensitive and Rapid UPLC-MS/MS Method for Determination of Monosaccharides and Anti-Allergic Effect of the Polysaccharides Extracted from Saposhnikoviae Radix. Molecules 2018, 23, 1924. [CrossRef] [PubMed]

61. Qin, X.-M.; Wang, S.-B. Detection of Monosaccharide Constituents in Saposhnikovia divaricata (Turcz.) Schichk Polysaccharides by HPCE. Chin. J. Spectrosc. Lab. 2013, 3, 95.

62. Wang, S.B.; Qin, X.M.; Liu, H.R.; Guo, X.Q.; Zhang, L.Z. Research for the Chemical Constituent of Saposhnikovia Divaricata (Turcz.) Schichk Polysaccharides. Chem. Res. 2008, 2.

63. Zhang, Z.Q.; Tian, Y.J.; Zhang, J. Studies on the antioxidative activity of polysaccharides from radix Saposhnikoviae. J. Chin. Med. Mater. 2008, 31, 268-272.

64. Li, L.; Yong, Z.; Li, Z. IN Vitro Effects of Fangfeng Polysaccharide and IL-2 on Mouse NK and LAK Cell Activity and Their in Vivo Effects of Inhibiting the Growth of S_ (180) Implanted Tumor. J. Beijing Univ. Tradit. Chin. Med. 1997, 5.

65. Liu, H.; Luo, Q.; Sun, L. Study on apoptosis of K562 cell in vitro induced by fangfeng polysaccharide. J. Clin. Hematol. 2008, 3. 
66. Dong, C.X.; Liu, L.; Wang, C.Y.; Fu, Z.; Zhang, Y.; Hou, X.; Peng, C.; Ran, R.X.; Yao, Z. Structural characterization of polysaccharides from Saposhnikovia divaricata and their antagonistic effects against the immunosuppression by the culture supernatants of melanoma cells on RAW264. 7 macrophages. Int. J. Biol. Macromol. 2018, 113, 748-756. [CrossRef] [PubMed]

67. Kuo, Y.C.; Lin, Y.L.; Huang, C.P.; Shu, J.W.; Tsai, W.J. A tumor cell growth inhibitor from Saposhnikovae divaricata. Cancer Invest. 2002, 20, 955-964. [CrossRef] [PubMed]

68. Chu, L.; Zhao, H.; Fang, J.; Li, C.; Liu, Z.; Cui, R.; Hu, F.; Zhang, X.; Chen, Y.; Han, H.; et al. The Traditional Chinese Medicinal Formula BDL301 Suppresses Tumor Growth by Inhibiting STAT3 Pathway and Inducing Apoptosis in Colorectal Cancer Cells. DNA Cell Biol. 2015, 34, 178-188. [CrossRef] [PubMed]

69. ChromaDex. Tech Tip 0003-Recovery \& Dilution Procedures. Available online: https://www.chromadex. com/media/2126/techtip0003-recoverydilutionprocedures_nl_pw.pdf (accessed on 20 June 2019).

70. Oyaizu, M. Studies on products of browning reactions: Antioxidative activities of products of browning reaction prepared from glucosamine. Jpn. J. Nutr. 1986, 44, 307-315. [CrossRef]

71. Matusiewicz, M.; Kosieradzka, I.; Niemiec, T.; Grodzik, M.; Antushevich, H.; Strojny, B.; Gołębiewska, M. In Vitro Influence of Extracts from Snail Helix aspersa Müller on the Colon Cancer Cell Line Caco-2. Int. J. Mol. Sci. 2018, 19, 1064. [CrossRef] [PubMed]

72. Sun, Y.; Hayakawa, S.; Ogawa, M.; Izumori, K. Antioxidant properties of custard pudding dessert containing rare hexose, D-psicose. Food Control 2007, 18, 220-227. [CrossRef]

73. Li, Y.; Zhang, L.; Wang, W. Formation of aldehyde and ketone compounds during production and storage of milk powder. Molecules 2012, 17, 9900-9911. [CrossRef]

74. Ellman, G.L. Tissue sulfhydryl groups. Arch. Biochem. Biophys. 1959, 82, 70-77. [CrossRef]

75. Dubois, M.; Gilles, K.A.; Hamilton, J.K.; Rebers, P.T.; Smith, F. Colorimetric method for determination of sugars and related substances. Anal. Chem. 1956, 28, 350-356. [CrossRef]

76. Bradford, M.M. A rapid and sensitive method for the quantitation of microgram quantities of protein utilizing the principle of protein-dye binding. Anal. Biochem. 1976, 72, 248-254. [CrossRef]

77. Folch, J.; Lees, M.; Sloane Stanley, G.H. A simple method for the isolation and purification of total lipides from animal tissues. J. Biol. Chem. 1957, 226, 497-509. [PubMed]

78. Singleton, V.L.; Orthofer, R.; Lamuela-Raventós, R.M. Analysis of total phenols and other oxidation substrates and antioxidants by means of folin-ciocalteu reagent. Methods Enzymol. 1999, 299, 152-178.

79. Tada, H.; Shiho, O.; Kuroshima, K.I.; Koyama, M.; Tsukamoto, K. An improved colorimetric assay for interleukin 2. J. Immunol. Methods 1986, 93, 157-165. [CrossRef] 